\title{
The Study on Large-Diameter Drilling Prevention Method of Rock Burst in the Xinxing Coal
}

\author{
Gao Xu (iD, Zuo Minghui, and Shu Yanmin \\ School of Energy and Mining, China University of Mining and Technology (Beijing), Beijing 100083, China \\ Correspondence should be addressed to Gao Xu; cumtb_gx@163.com
}

Received 19 November 2020; Revised 1 April 2021; Accepted 23 April 2021; Published 8 May 2021

Academic Editor: Yanlin Zhao

Copyright (C) 2021 Gao Xu et al. This is an open access article distributed under the Creative Commons Attribution License, which permits unrestricted use, distribution, and reproduction in any medium, provided the original work is properly cited.

\begin{abstract}
Based on the engineering background, the 41051 working face of the 65th coal mine in Qitaihe Xinxing Mine was regarded as the engineering background, by using of the comprehensive research methods such as theoretical analysis and calculation, FLAC3D numerical simulation, physical parameters of coal and rock in laboratory, and the field industrial measurement, to research on the large drilling relieving rock burst mechanism and parameter setting in reasonable. The distribution of stress and plastic zone in drilling surrounding rock and its influence parameters are clarified, and the distribution of the "butterfly plastic zone" and the mutation condition of the "butterfly plastic zone" in trigger stress state are explored. On the basis, combined with theoretical analysis and numerical simulation, studying the rock burst prevention and treatment mechanism in large drilling, through the statistics of the Xinxing mine pressure characteristics, the measurement of the physical parameters of coal and rock and the test of ground stress finding is that the coal satisfies "Three hard" condition in Xinxing mine and is affected by larger horizontal tectonic stress. Combined with the real geological conditions, the layout parameters of relief pressure large drilling are simulated, and the result shows that the drilling of 600 diameters and $10 \mathrm{~m}$ pitch of hole and throughout the working face is reasonable, and the effect is obvious about pressure relief. For the practical implementation, the electromagnetic radiation monitoring is used to evaluate the effect in field; to comprehensive analysis, the relief pressure large drilling has obvious control effect to the 41051 workface rock burst.
\end{abstract}

\section{Introduction}

Since the mining of Qitaihe Xinxing Coal Mine, rock bursts have occurred many times [1-4], and with the increase of mining depth, impact disasters increase significantly and have a more serious trend, resulting in huge losses in coal mine safety production $[5,6]$. The causes of rock bursts in Qitaihe Xinxing Coal Mine are complex with many influencing factors $[7,8]$, and emerging mines usually adopt several measures commonly used in the industry and manage with experience all the time, but the effect is not ideal. How to effectively manage rock burst has not been studied in depth yet, nor has it formed a method of rock burst prevention and control that is in line with the characteristics of its own coal mine. In recent years, with the continuous improvement of science and technology, the research on the prevention and control measures of rock burst has also been constantly improved, and the pressure relief method has made rapid progress. A variety of methods have been successfully used to prevent rock burst at home and abroad [9-11]. Rock burst is the dynamic behavior of mine pressure where coal rock around mining space is characterized by coal rock outburst under mining pressure, and it is a major coal mine accident [12-15]. For the cause of rock burst, academics generally believe that roadway excavation and face mining lead to the release of elastic energy from coal and rock. The active relief measures of rock burst are mainly adopted pressure-relief blasting, coal seam water injection, borehole pressure relief, high pressure hydraulic fracturing, etc. [16-19], by taking measures for high stress areas, changing the stress distribution state, and transferring and releasing elastic energy stored in coal and rock, through the drilling of large diameter, forming a broken area around the borehole, decompressing the coal seam, and releasing the stored elastic energy, so as to achieve the purpose of decompression and relief [20-23]. In this paper, the large-diameter boreholes in coal roadway 


\begin{tabular}{|c|c|c|c|c|c|}
\hline $\begin{array}{l}\text { Roof and } \\
\text { floor } \\
\text { classification }\end{array}$ & Type & $\begin{array}{c}\text { Thick- } \\
\text { ness }(\mathrm{m})\end{array}$ & Columnar & Coal name & $\begin{array}{l}\text { Lithology } \\
\text { description }\end{array}$ \\
\hline Old roof & & $18 \sim 20$ & & $\begin{array}{l}\text { Coarse } \\
\text { sandstone }\end{array}$ & Hard \\
\hline \multirow[t]{2}{*}{ Coal } & & 0.2 & & Coal & $\begin{array}{c}\begin{array}{c}\text { Bright black. } \\
\text { harder }\end{array} \\
\end{array}$ \\
\hline & & 1.7 & $\begin{array}{lll}\cdots: \cdots \\
\cdots \cdots & \cdots\end{array}$ & $\begin{array}{c}\text { Fine } \\
\text { sandstone }\end{array}$ & $\begin{array}{c}\text { Off-white, hard } \\
\text { underdeveloped bedding }\end{array}$ \\
\hline Direct roof & & 2.8 & & Siltstone & Off-white, harder \\
\hline Coal & $58^{\#}$ & 0.85 & $\cdot$ & Coal & $\begin{array}{c}\text { Bright black. } \\
\text { harder }\end{array}$ \\
\hline \multirow[t]{3}{*}{ Direct floor } & & 1.2 & & $\begin{array}{c}\text { Fine } \\
\text { sandstone }\end{array}$ & $\begin{array}{l}\text { Off-white, hard } \\
\text { the layering is not obvious }\end{array}$ \\
\hline & & 4.0 & & Siltstone & Gray, hard \\
\hline & & 2.8 & & $\begin{array}{c}\text { Fine } \\
\text { sandstone }\end{array}$ & Off-white, hard \\
\hline Old floor & & $>4$ & $\begin{array}{c}\cdots \\
\cdots \\
\cdots \\
\cdots\end{array}$ & Siltstone & Gray, hard \\
\hline
\end{tabular}

Figure 1: Top and bottom histogram.

pressure-relief mechanism and reasonable parameters' further research will be conducted. At the same time, it analyzes the layout direction, diameter, hole spacing, hole depth parameters, and their reasonable combinations of largediameter boreholes, to provide extremely important theoretical support for the practical application and popularization of large-diameter borehole pressure-relief technology and has great practical application value.

\section{Profile}

2.1. Properties of Coal and Ground Stress. The total thickness of the coalfield stratum is $847 \mathrm{~m}$, with 16 layers of coal. The occurrence of coal seam is stable, floor formation, small change, and simple structure of coal seam. The total thickness of the coal seam is $28.51 \mathrm{~m}$. There are 6 main minable coal seams, namely, 48, 58, 63, 65, 67, and 68 layers. There are 10 layers of locally minable coal seam, respectively, 41 , $46,47,49,51,56,60,66,73$, and 74 layers. The coal thickness is between 0.7 and $2.2 \mathrm{~m}$, with an average of $0.8 \mathrm{~m}$, and the inclination angle is $8^{\circ}-30^{\circ}$, with an average of $20^{\circ}$. The coal seam is stable. The roof and floor of each coal seam are sandstone, most of the coal seam roof is good, part of the coal seam has pseudo roof, generally the pseudo roof is siltstone and carbonaceous shale, the direct roof is fine sand rock, there are thin layers of medium sandstone in part, and the old roof is generally medium coarse sandstone, as shown in Figure 1.

According to the research needs, the physical and mechanical properties of coal and rock and the sturdiness coefficient of coal in the 58 and 65 layers of the six mining areas were experimentally tested, and the results are shown in Tables 1-3.

It can be seen from the experimental results in Tables 1 and 2 that the coal seam, roof, and floor of the Xinxing coal mine have high compressive strength, which is conducive to the storage of higher energy of the coal body. The high energy stored in the coal body cannot be released, which may lead to the occurrence of dynamic phenomena such as rock burst. It can be seen from Table 3 that the roof, floor, and coal seam of the Xinxing coal mine are relatively hard and have the ability to gather a large amount of elastic energy. Once the conditions are met, the accumulated elasticity can be released instantly, causing the occurrence of rock burst. The hard roof causes a large area of suspended plate, resulting in a large amount of elastic energy accumulation in the coal body. The coal seam is hard, the plastic zone is small, and the peak position of abatement pressure is close to the facing surface, making the working face easy to impact and the coal will eject out.

According to the measured ground stress data, the in-site measured data are processed, and the magnitude and direction of the ground stress component and the principal stress of the three measuring points are calculated as shown in Table 4.

According to the results of ground stress test, the distribution of ground stress in Xinxing coal mine is as follows:

(1) The maximum principal stress inclination angles of the three measuring points are $1.65^{\circ}, 7.67^{\circ}$, and $1.70^{\circ}$, and the average value of the inclination angle 


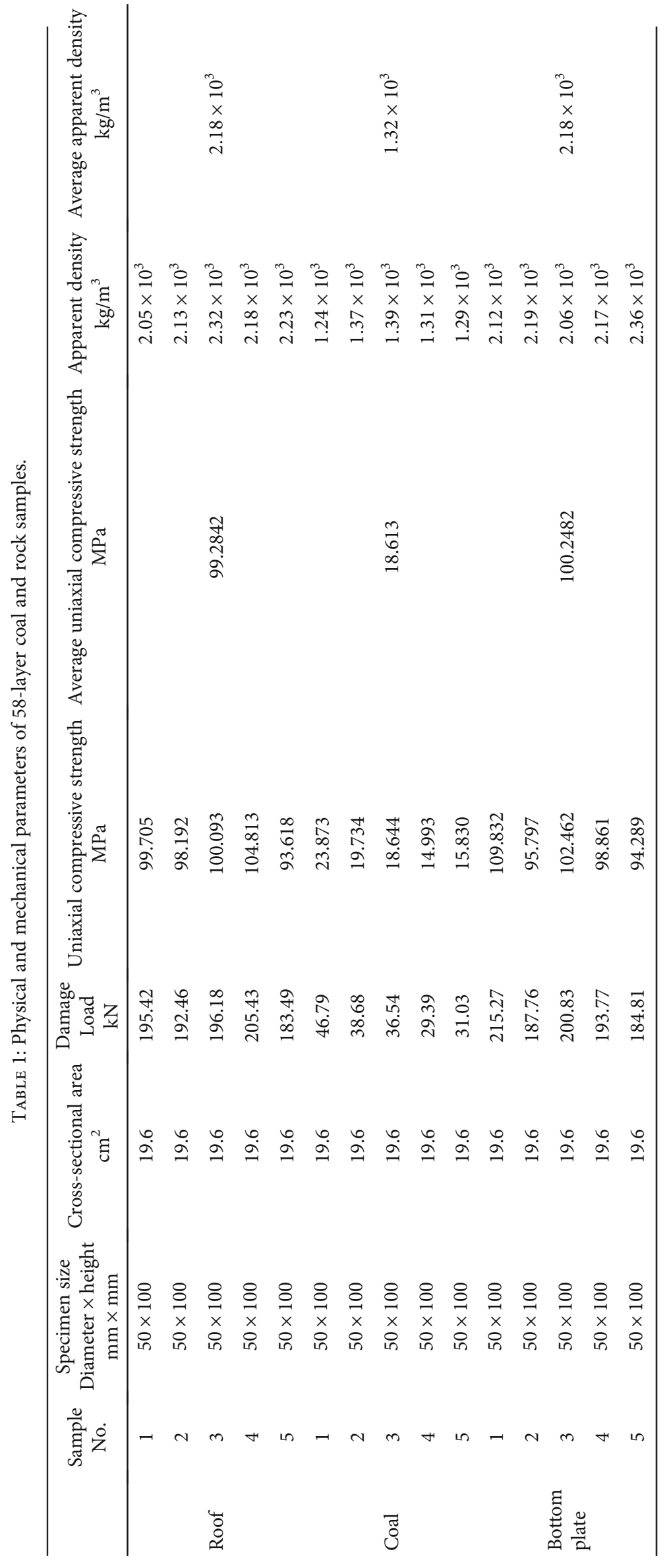




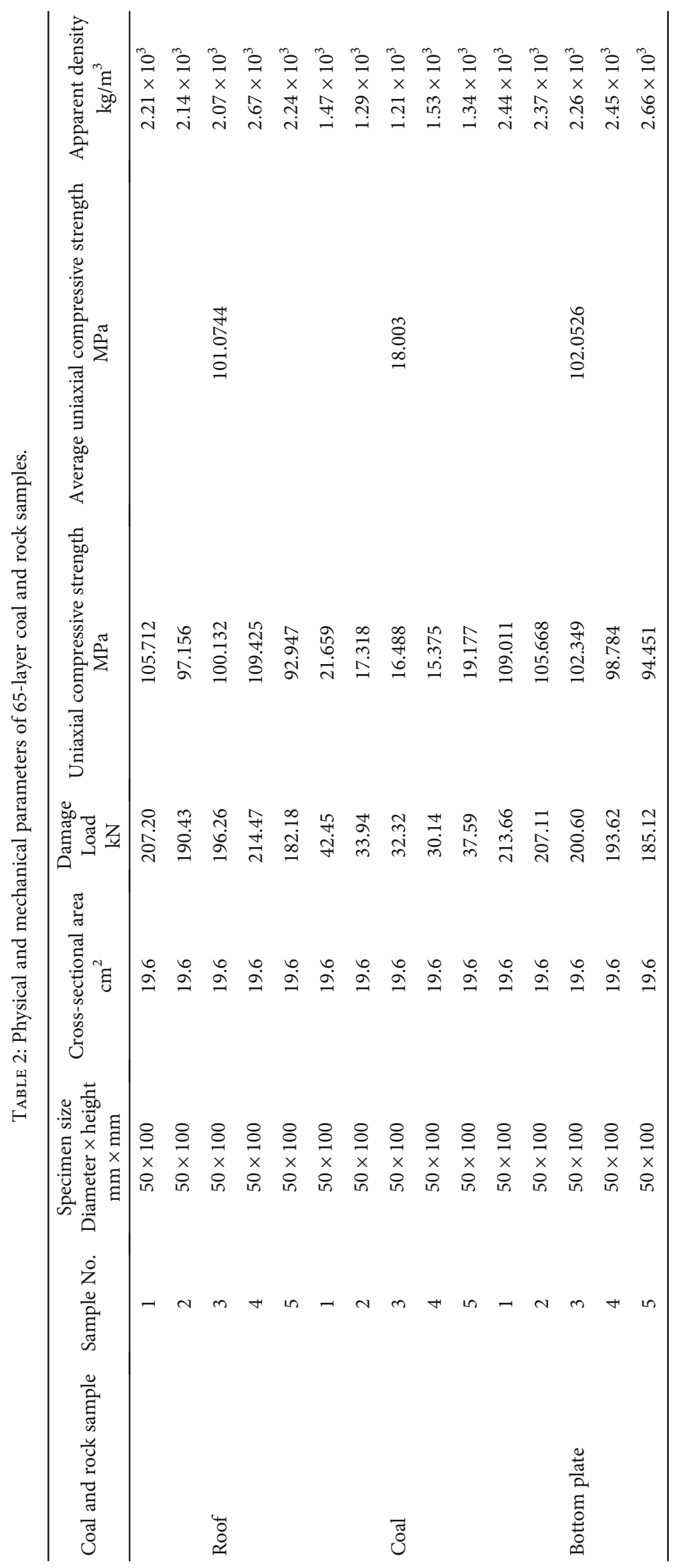


TABLE 3: Experimental results of coal sample firmness coefficient.

\begin{tabular}{lccccc}
\hline Sampling location & $\begin{array}{c}\text { Sample } \\
\text { No. }\end{array}$ & $\begin{array}{c}\text { Number of } \\
\text { impacts }\end{array}$ & $\begin{array}{c}\text { Measuring cylinder } \\
\text { reading l/mm }\end{array}$ & $\begin{array}{c}\text { Test piece firmness } \\
\text { factor } \mathrm{f}\end{array}$ & $\begin{array}{c}\text { Average value of sample firmness } \\
\text { coefficient }\end{array}$ \\
\hline 58th floor of the sixth & 1 & 3 & 67.5 & 1.888888889 & 1.90 \\
mining area & 2 & 3 & 65.5 & 1.916030534 & 1.895522388 \\
& 3 & 3 & 67.0 & 1.857142857 & 1.87 \\
65th floor of the sixth & 1 & 3 & 60.0 & 1.923076923 & \\
mining area & 2 & 3 & 72.0 & 1.833333333 & \\
& 3 & 3 & & & \\
\hline
\end{tabular}

TABLE 4: Summary table of ground stress measurement.

\begin{tabular}{|c|c|c|c|c|c|c|c|}
\hline \multirow{2}{*}{ Borehole position } & \multirow{2}{*}{ Depth/m } & \multirow{2}{*}{ Measuring point } & \multicolumn{4}{|c|}{ Main stress } & \multirow{2}{*}{ Vertical stress/Mpa } \\
\hline & & & Stress & Value/MPa & Azimuth $/^{\circ}$ & Inclination $/^{\circ}$ & \\
\hline \multirow{3}{*}{$\begin{array}{l}\text {-600 West Sixth District } \\
\text { Main Transport Alley }\end{array}$} & \multirow{3}{*}{807.4} & \multirow{3}{*}{$1 \#$} & $\sigma_{1}$ & 28.54 & 172 & 1.65 & \multirow{3}{*}{20.19} \\
\hline & & & $\sigma_{2}$ & 14.19 & 84 & -37.39 & \\
\hline & & & $\sigma_{3}$ & 13.93 & 260 & -52.56 & \\
\hline \multirow{6}{*}{$\begin{array}{l}-600 \text { three-level substation } \\
\text { in the fifth mining area }\end{array}$} & \multirow{6}{*}{780} & & $\sigma_{1}$ & 26.81 & 154 & 7.67 & \multirow{3}{*}{19.5} \\
\hline & & $2 \#$ & $\sigma_{2}$ & 13.56 & 44 & 68.19 & \\
\hline & & & $\sigma_{3}$ & 12.32 & 247 & 20.29 & \\
\hline & & \multirow{3}{*}{$3 \#$} & $\sigma_{1}$ & 27.09 & 160 & 1.70 & \multirow{3}{*}{19.5} \\
\hline & & & $\sigma_{2}$ & 13.51 & 72 & -39.49 & \\
\hline & & & $\sigma_{3}$ & 13.30 & 248 & -50.47 & \\
\hline
\end{tabular}

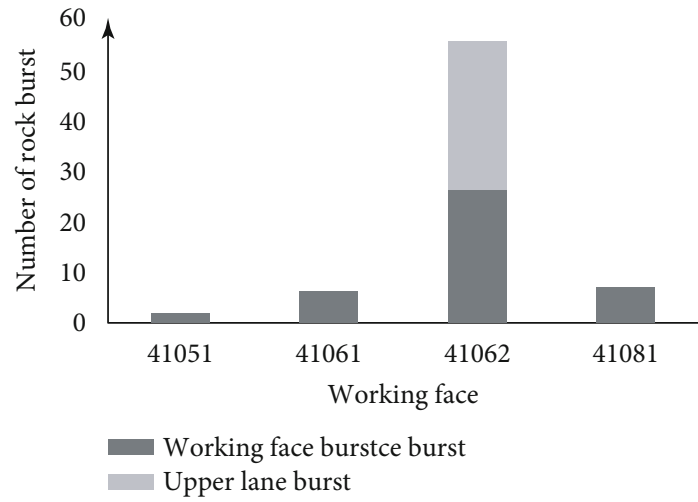

Figure 2: Statistics of occurrences of rock bursts on working face.

is $3.67^{\circ}$. It shows that the maximum main stress of Xinxing coal mine is horizontal direction, and the maximum main stress is $1.37 \sim 1.41$ times of the selfweight stress, and the ground stress field is mainly horizontal tectonic stress field

(2) The maximum main stress azimuth angles of the 3 measuring points are $172^{\circ}, 154^{\circ}$, and $160^{\circ}$, which basically determined that the maximum main stress direction of the tectonic stress field in Xinxing coal mine is roughly northwest-southeast. The maximum main stress is 2.04 2.18 times of the minimum main stress. Therefore, the tectonic stress is one of the main factors that cause rock burst. The influence of tec-

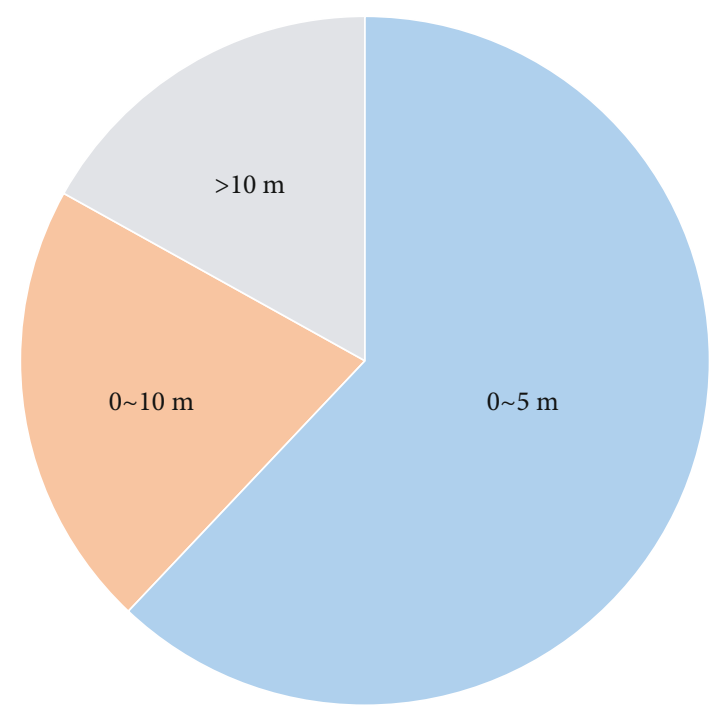

Figure 3: Statistics of impact scope of working face.

tonic stress should be fully considered in the design and arrangement of mine exploitation in the future

(3) From the test results of the maximum main stress, vertical main stress, and minimum main stress, it can be concluded that in the -600 mining level, the maximum main stress gradient is $0.0353 \mathrm{MPa} / \mathrm{m}$, the vertical main stress gradient is $0.025 \mathrm{MPa} / \mathrm{m}$, and the minimum main stress gradient is $0.0158 \mathrm{MPa} / \mathrm{m}$ 


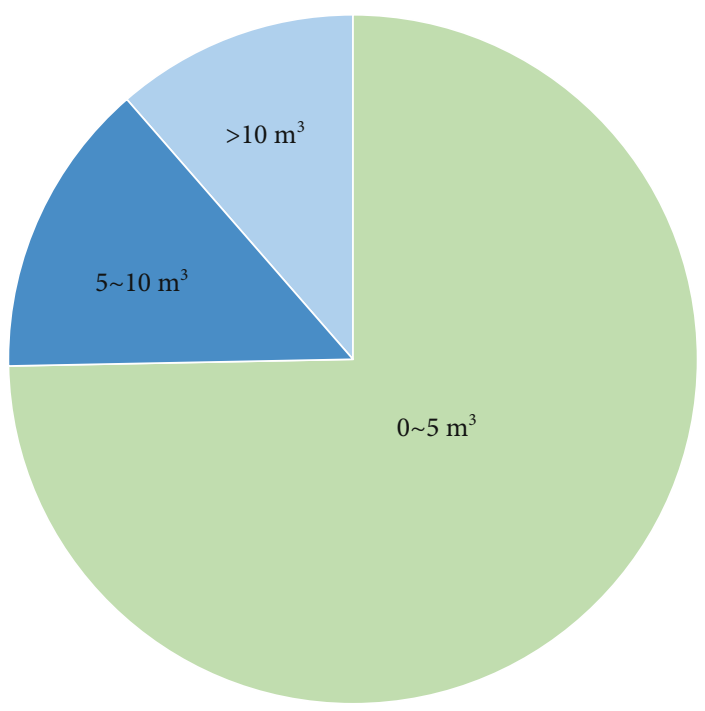

FIgURE 4: Statistics of shipment volume of working face impact.

TABLE 5: Three-level 65-story roof and floor features.

\begin{tabular}{ccccc}
\hline \multicolumn{2}{c}{ Roof and floor } & Rock type & Thickness $(\mathrm{m})$ & Lithology \\
\hline \multirow{2}{*}{ Roof } & Old roof & Coarse sandstone & 19 & Hard \\
& Direct roof & Fine sandstone $\sim$ siltstone & 35 & Gray black gray \\
\multirow{2}{*}{ Floor } & Direct floor & Fine sandstone & 1.2 & Off-white hard, not obvious layering \\
& Old floor & Fine sandstone $\sim$ siltstone & 6.8 & Off-white dense and hard \\
\hline
\end{tabular}

\subsection{Analysis of Rock Burst}

2.2.1. Statistical Analysis of Rock Burst. Since June 22, 2007, Xinxing mine has experienced 71 rock bursts. Among them, the coal mining face occurred 42 times, accounting for $59.2 \%$ of the total, and the return air drift occurred 29 times, accounting for $40.8 \%$ of the total. 41051 working face has occurred 2 shocks, 41061 working face has occurred 7 times, 41062 working face has occurred 55 times, and 41081 working face has occurred 7 times, the statistics of the number of occurrences of rock burst Figure 2. Among them, the rock bursts on the 41051, 41061, and 41081 working faces are all on the working face, and the rock bursts on the 41062 working face have occurred 29 times on the upper lane and 26 times on the working face.

The impact range of rock burst in Xinxing mine is small, as shown in Figure 3, and most are within the range of $0 \sim 10 \mathrm{~m}$. The statistical results of the whole mine show that $62 \%$ of the impacts have an impact range of $0-5 \mathrm{~m}, 21.1 \%$ have an impact range of $6-10 \mathrm{~m}$, and $16.9 \%$ have an impact range of $10 \mathrm{~m}$ or more. The shipment volume of rock burst is small, as shown in Figure 4, which is mostly around $5 \mathrm{~m}^{3}$. The statistical results of the whole mine show that $74.6 \%$ of the impact shipments are from 0 to $5 \mathrm{~m}^{3}, 14.1 \%$ are for the shipments from 6 to $10 \mathrm{~m}^{3}$, and $11.3 \%$ are for the total shipments above $10 \mathrm{~m}^{3}$.

2.2.2. Characteristic Analysis of Rock Burst. Through the statistical analysis of the characteristics and laws of rock burst occurring on the main working face and upper roadway of the Xinxing mine, it is found that the rock burst has the following main characteristics:

(1) The top and bottom plates are hard. The roof and floor of the coal seam where the rock burst occurs in Xinxing mine are sandstone, and the thickness is relatively large, as shown in Table 5. Due to the hardness of the roof and the coal seam belongs to hard coal, it has the condition of a lot of elastic energy gathering. When the load of coal exceeds its strength, a lot of elastic energy will be released instantaneously, which will cause the impact of coal on working face

(2) Most of the rock burst in Xinxing mine occurs in the mining influence period of working face, and some occurs in the process of roadway tunneling. It can be seen that the stress redistribution of surrounding rock caused by mining activities is one of the dynamic factors of rock burst

(3) The section coal pillars, the upper section goaf, and the roof of the goaf of its own working face work together to cause greater stress concentration on the upper part of the working face, obvious advance pressure on the working face, and frequent shocks

(4) Due to the hardness of roof, floor, and coal seam, the stress in front of the working face is concentrated. Before the impact, the plastic zone and 
influence range are small, most of which are within $10 \mathrm{~m}$, and the coal and rock shipments are not large at the time of impact. Therefore, the prevention and treatment of rock burst in emerging mines mainly focuses on the front of the working face within $10 \mathrm{~m}$

\section{Mechanism Analysis of Rock Burst Relief}

3.1. Analysis of the Abrupt Expansion of the Boundary. According to the analysis of previous research results [2426], under the state of nonuniform stress field, the plastic zone of the surrounding rock of the borehole shows a "butterfly-shaped" distribution. When analyzing the influence of different lateral pressure coefficients on the distribution of the plastic zone of the surrounding rock of the borehole, it is found that when $\lambda$ increases to a certain value, the boundary of the "butterfly-shaped plastic zone" of the surrounding rock of the borehole will undergo abrupt changes.

(1) Butterfly leaf radius $R_{\max }$ and butterfly leaf radius angle $\theta_{R}$ in butterfly-shaped plastic zone

As shown in Figure 5, $R_{\max }$ represents the radius of the butterfly-shaped leaf in the butterfly-shaped plastic zone, that is, the maximum depth of the boundary of the butterfly-shaped plastic zone, and represents the butterfly leaf radius angle. The radius of the butterfly leaf refers to the maximum distance between the boundary of the "butterfly-shaped plastic zone" of the surrounding rock of the borehole and the center of the borehole circle, and the radius angle of the butterfly leaf refers to the included angle between the radius of the butterfly leaf and the vertical axis of the borehole, namely, the polar coordinate angle.

(2) The sharp expansion of the boundary of the butterfly-shaped plastic zone

The butterfly leaf radius $R_{\max }$ of the butterfly-shaped plastic zone of the surrounding rock of the borehole will increase with the increase of the lateral pressure coefficient $\lambda$ of the stress field of the surrounding rock of the borehole, and the change rate of $R_{\max }$ will gradually increase with the increase of $\lambda$ [27-29]. When a certain critical condition value is reached, the $R_{\max }$ growth trend will undergo abrupt changes, and the butterfly-shaped plastic zone of the boreholes will expand rapidly, as shown in Figure 6.

3.2. Mechanism of Rock Burst in Working Face. As shown in Figure 7, a numerical model for rock burst in Xinxing coal mine and large-diameter borehole to relieve rock burst is established, and then, numerical simulation analysis is performed.

Rock burst is the phenomenon that the coal and rock in front of the working face is destroyed and ejected instantaneously. The plastic zone describes the failure state of coal and rock from the perspective of elastic-plastic mechanics. Figures 8(a) and 8(b), respectively, show the

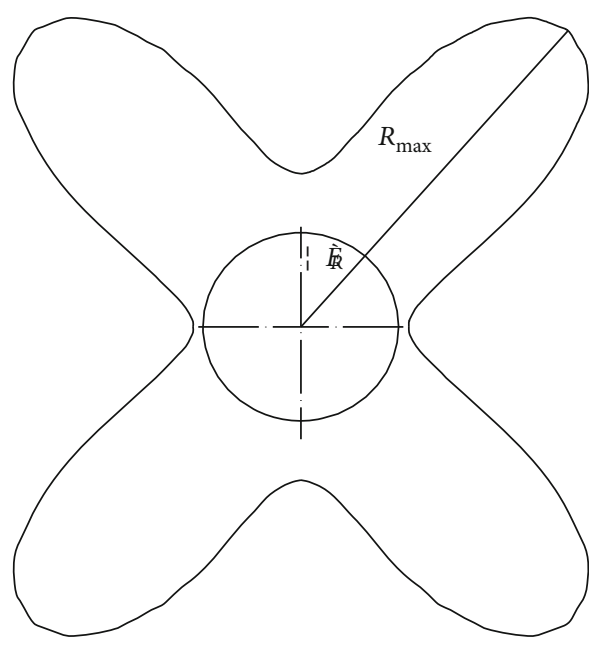

FIGURE 5: Butterfly-shaped plastic zone.

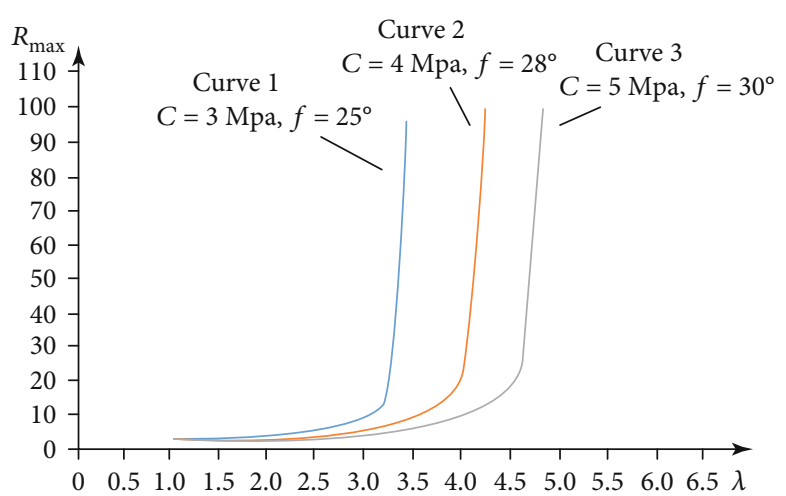

Figure 6: Trend of butterfly leaf radius with lateral pressure coefficient.

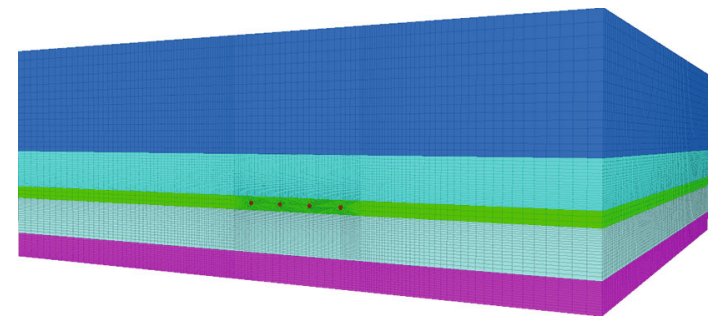

Figure 7: Numerical simulation model

distribution of plastic zone in front of the working face before impact and after impact caused by mining. Analysis shows that under the influence of mining, the coal plastic zone in front of the working face appears malignant expansion. Therefore, the Xinxing coal mine's rock burst is the result of the instantaneous vicious expansion of the plastic zone of the coal and rock in the working face under the influence of mining.

3.3. The Crisis of Large-Diameter Drilling. Figures 9(a) and 9 (b), respectively, show the distribution of plastic zone in 


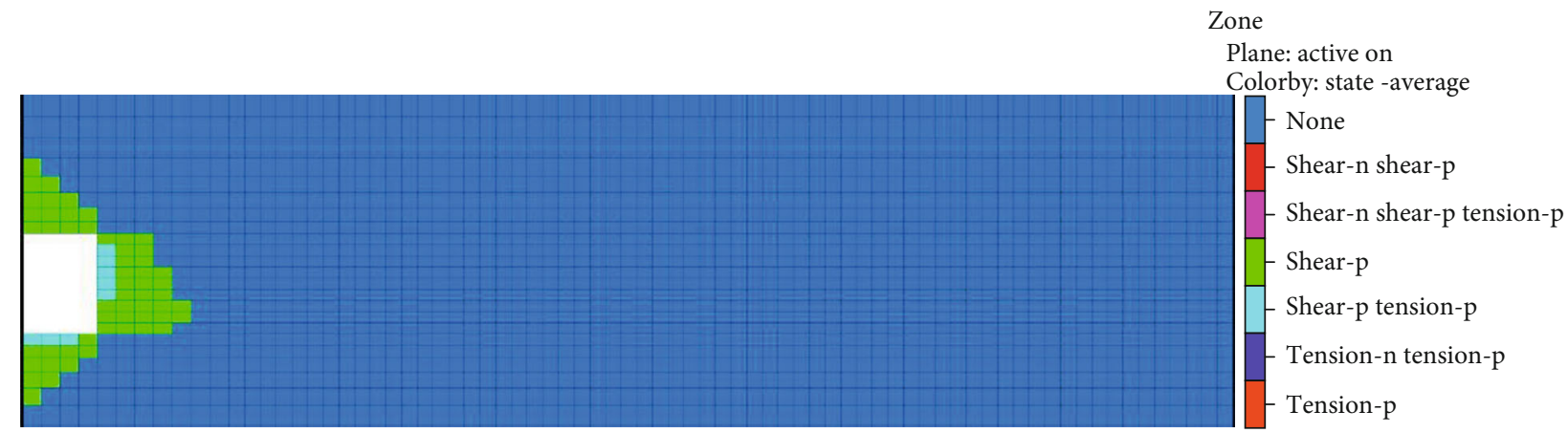

(a) Distribution of plastic zone in front of work before impact

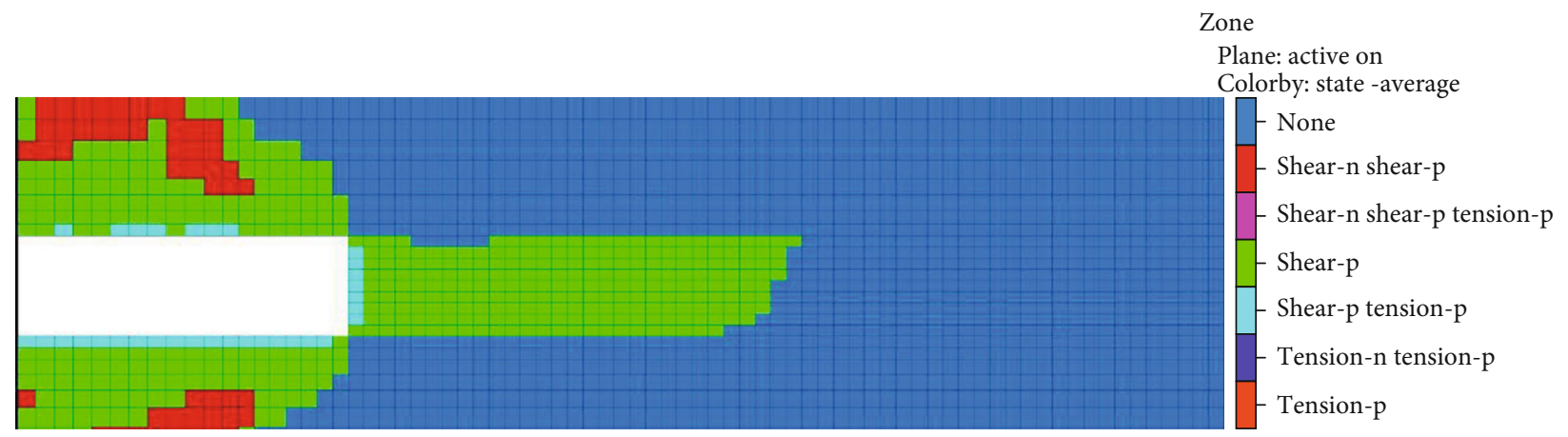

(b) Distribution of plastic zone in front of the working face after the impact of mining

FIGURE 8: Change of plastic zone in working face affected by mining.

surrounding rock under the influence of mining with largediameter pressure-relief boreholes. The figure shows that under the influence of mining, the plastic zone of surrounding rock of four large-diameter boreholes presents the distribution of "butterfly-shaped plastic zone." The farther away from the working surface, the smaller the "butterfly-shaped plastic zone" of the drilling hole. With the continuous advancement of the working face, the "butterfly leaf radius" of each borehole plastic zone will continue to expand and eventually penetrate each other. The concentrated stress of the coal body in front of the working face acts on the pressure-relief borehole, causing the surrounding rock of the pressure-relief borehole to rupture, forming a largescale plastic zone, so that the concentrated stress and the elastic energy accumulated in the coal body can be released in advance and play a role in preventing rock burst.

Through theoretical calculation and numerical simulation analysis, it can be seen that when the lateral pressure coefficient $\lambda$ of the stress field in the surrounding rock area of a large-diameter borehole reaches a critical condition, a small increase will occur, which can lead to a huge increase in the butterfly leaf radius $R_{\max }$ in the "butterfly plastic zone" of the borehole. The increase of the lateral pressure coefficient $\lambda$ of the stress field in the surrounding rock region can be an increase in the maximum main stress (loading) or a decrease in the minimum main stress (unloading) or both. Before the lateral pressure coefficient $\lambda$ of the regional stress field reaches the critical value, the size of the butterfly leaf in the "butterfly-shaped plastic zone" of the surrounding rock of the borehole changes uniformly. When the lateral pressure coefficient $\lambda$ is slightly larger than the critical value, the size of the butterfly leaf in the "butterfly-shaped plastic zone" will increase sharply, that is, the butterfly leaf in the "butterfly-shaped plastic zone" of the surrounding rock of the boreholes will explode and suddenly fail, which is also the reason why the hole can relieve the pressure in advance to prevent the impact phenomenon.

\section{Layout Scheme of Boreholes}

4.1. Numerical Model. As shown in Figure 10, the average thickness of the 65-layer coal 41051 working face is $2.0 \mathrm{~m}$, the average inclination is $26^{\circ}$, the inclined length of the working face is $155 \mathrm{~m}$, and the coal seam mining depth is about $500 \mathrm{~m}$. The false roof of the coal seam is fine sandstone, $1 \sim 2.9 \mathrm{~m}$ thick; the direct roof is siltstone, $35 \mathrm{~m}$ thick; the old roof is medium-coarse sandstone, $19 \mathrm{~m}$ thick; the direct bottom is fine sandstone, $1 \mathrm{~m}$ thick; the old bottom is siltstone, $7 \mathrm{~m}$ thick. The coal seam and the roof and floor meet the "three hard" conditions, and the overlying roof is thick and hard. Therefore, elastic energy is easy to accumulate in the coal seam, so that it is qualified for the occurrence of rock burst. Due to the downlink mining sequence, the 41051 working face is affected by the goaf in the upper section and coal pillars and other factors, and the area around the roadway on the working face is under long-term strong pressure. Therefore, the stress concentration in the upper corner is relatively large. In 


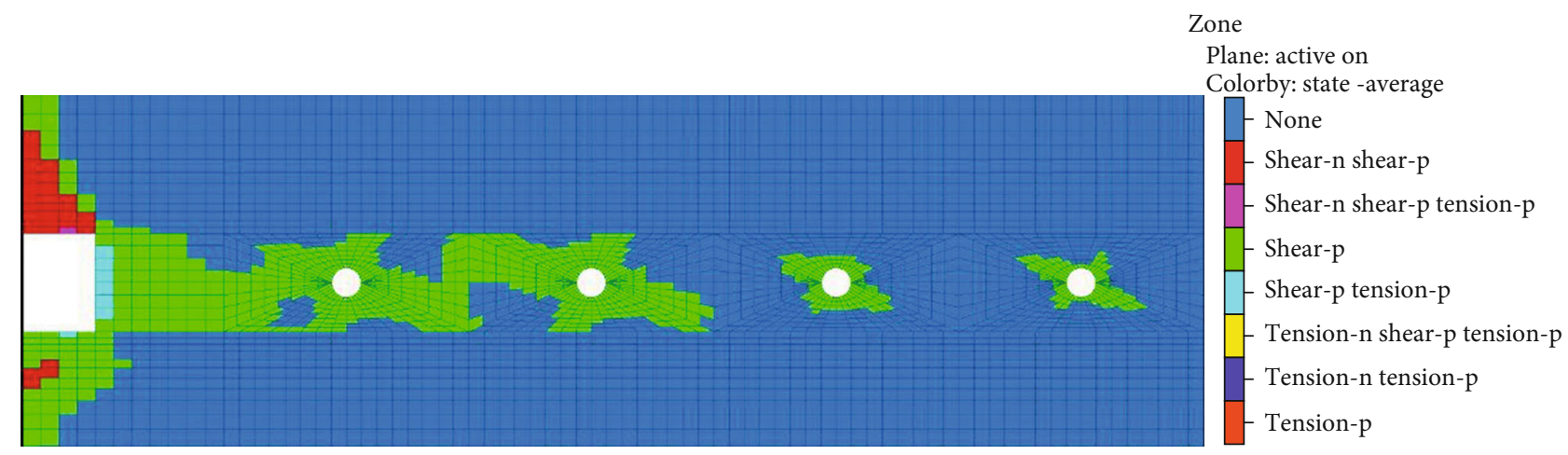

(a) Distribution of plastic zones in large-diameter drill holes in front of the working face

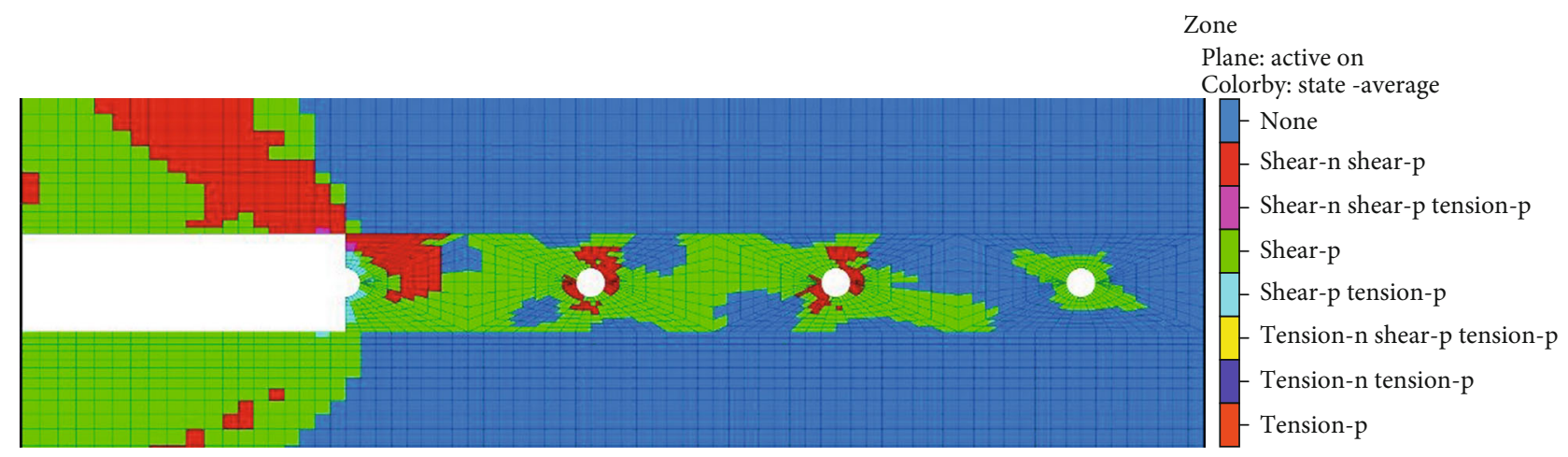

(b) The plastic zone distribution of the large-diameter borehole in the front after the working face advances

FIGURE 9: Plastic zone changes in surrounding rock of large-diameter boreholes.

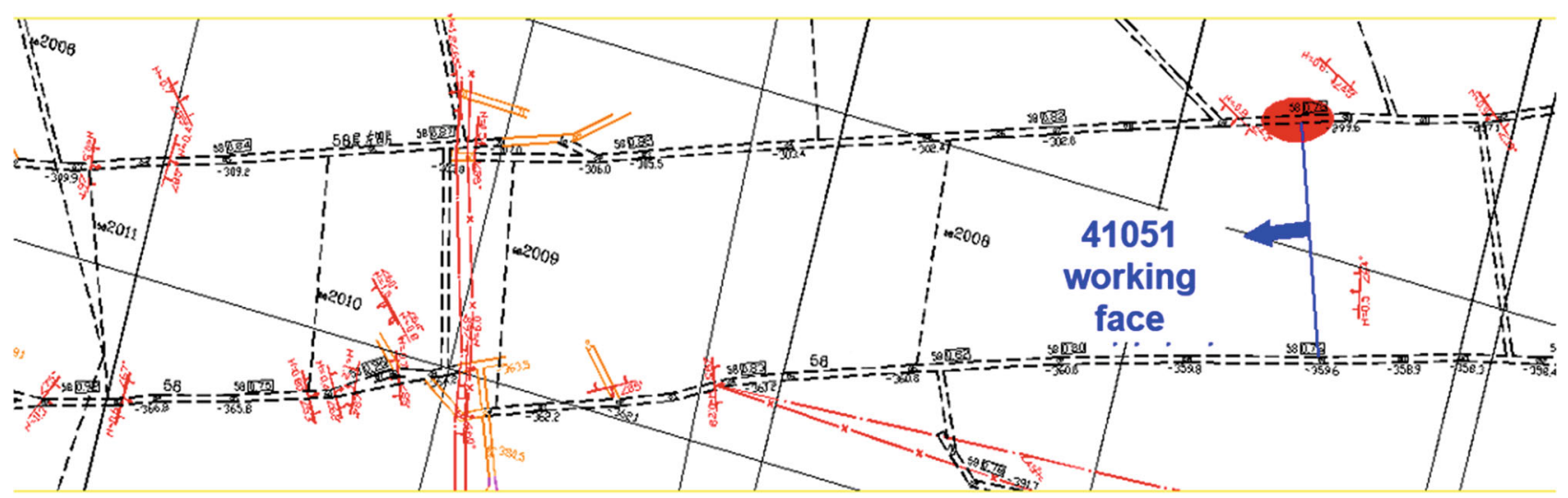

Figure 10: Schematic diagram of 41051 working face layout.

addition, the coal rock has a large inclination angle, and the roof rock layer in the goaf has a tendency to collapse in the direction of the working face under the action of gravity. Therefore, the lower end of the working face also receives a relatively large stress, which further creates condition for the occurrence of rock bursts.

According to the field measurement of ground stress above, the maximum main stress in the horizontal direction is about 1.37 1.41 times that in the vertical direction, so the lateral pressure coefficient is 1.4 . The numerical model is $500 \mathrm{~m}$ long, $500 \mathrm{~m}$ wide, and $600 \mathrm{~m}$ high, as shown in Figure 11. The thickness of the coal seam is $2 \mathrm{~m}$, the initial stress of the model is the self-weight stress of the overlying surrounding rock and the horizontal ground stress, and the fixed velocity of the left and right, front and back, and lower parts of the model remains unchanged, while fixed constraints are used at the bottom of the model. This model mainly studies the shape and distribution law of plastic zone in working face stope and large borehole surrounding rock, using Mohr-Coulomb strength criterion based on elastoplastic theory. The mechanical parameters of coal and rock are shown in Table 6.

4.2. Layout of Solution Drilling. Based on the knowledge of elastoplastic mechanics, the unloading pressure model of 


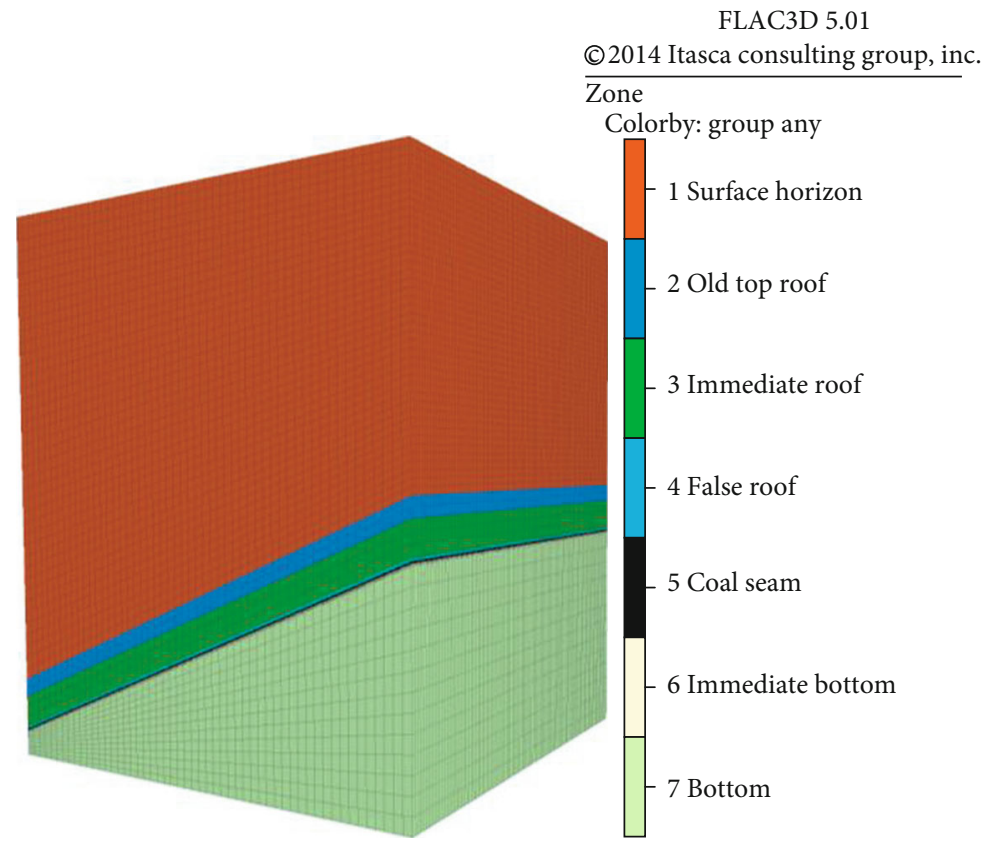

FIGURE 11: Simplified diagram of numerical modeling.

TABLE 6: Physical and mechanical parameters of coal.

\begin{tabular}{|c|c|c|c|c|c|c|}
\hline Lithology & Density $/ \mathrm{kg} / \mathrm{m}^{3}$ & $\begin{array}{c}\text { One-way tensile } \\
\text { strength/MPa }\end{array}$ & $\begin{array}{c}\text { Bulk } \\
\text { modulus/GPa }\end{array}$ & $\begin{array}{c}\text { Shear } \\
\text { modulus/GPa }\end{array}$ & Cohesion/MPa & $\begin{array}{c}\text { Internal friction } \\
\text { angle } /^{\circ}\end{array}$ \\
\hline $\begin{array}{l}\text { Loading medium coarse } \\
\text { sandstone }\end{array}$ & 2707 & 108.88 & 18.17 & 12.07 & 14.5 & 37 \\
\hline Direct top siltstone & 2270 & 97.07 & 10.8 & 10.01 & 10.7 & 40 \\
\hline Pseudo top fine sandstone & 2180 & 78.05 & 5.17 & 7.14 & 7.2 & 28 \\
\hline Coal & 1370 & 18.35 & 2.46 & 1.77 & 2.7 & 25 \\
\hline $\begin{array}{l}\text { Direct bottom fine } \\
\text { sandstone }\end{array}$ & 2180 & 98.05 & 5.17 & 7.14 & 7.2 & 30 \\
\hline Old siltstone & 2440 & 94.25 & 12.8 & 10.01 & 10.7 & 40 \\
\hline
\end{tabular}

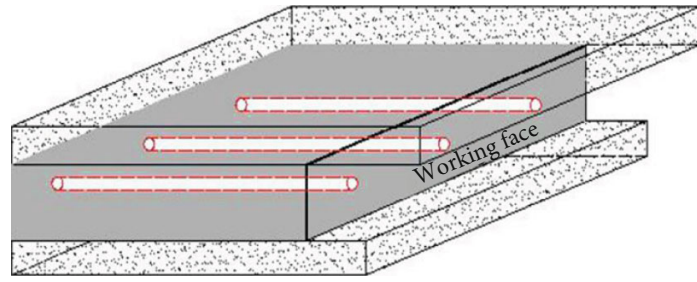

(a) Layout along the working face strike

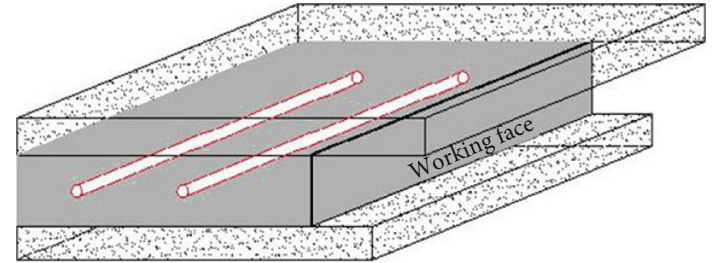

(b) Layout along the working face trend

Figure 12: Simplified diagram of drilling holes in different layout directions.

large-diameter boreholes is established and the mechanism of unloading pressure of large-diameter boreholes is analyzed. The determination of borehole layout parameters is the key factor for large-diameter borehole pressure-relief prevention and control. Reasonable layout parameters of large-diameter borehole are related to the treatment effect of working face rock burst. It can be seen from the previous study that the parameters of largediameter boreholes mainly include the layout direction, borehole diameter, borehole spacing, and borehole depth. Select different layout directions, borehole diameters, borehole spacings, and borehole depths, and use FLAC3D large-scale numerical simulation software to perform simulation calculations to obtain more reasonable and 


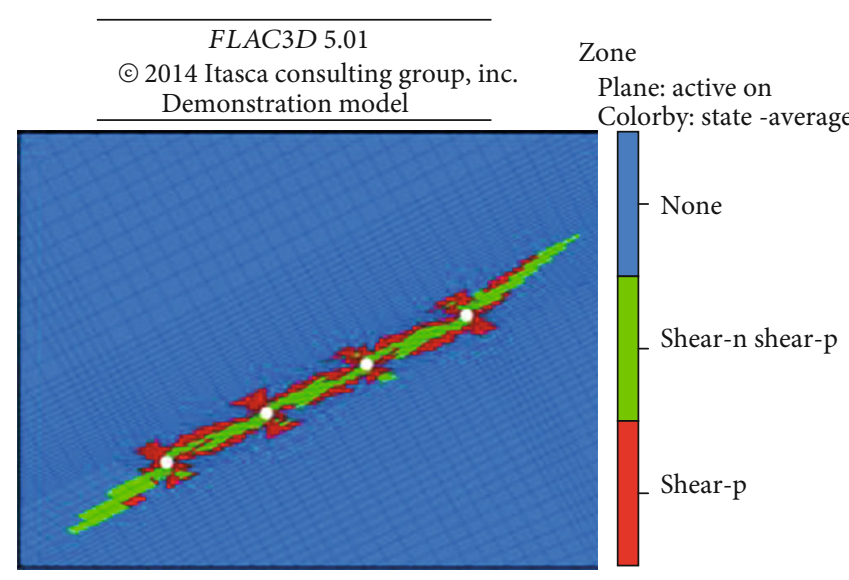

(a) $4 \mathrm{~m}$ cross section in front of the work front (close to the upper lane)

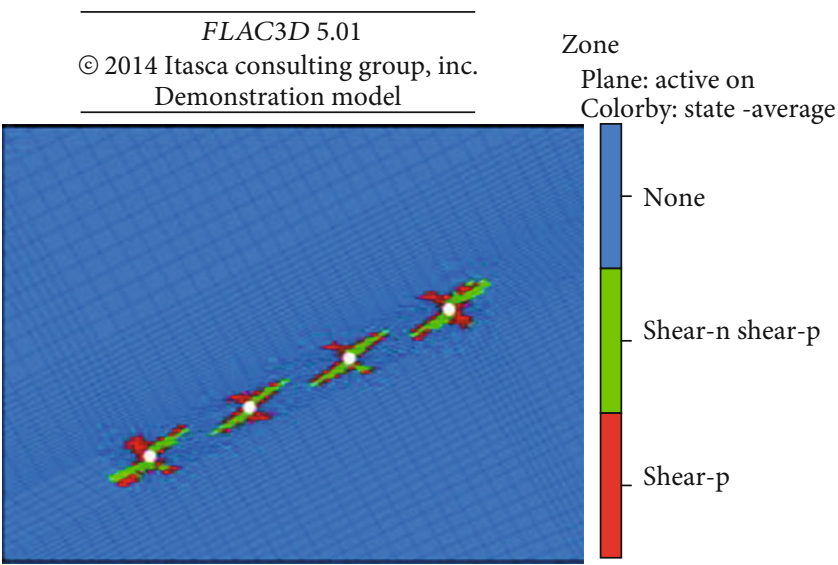

(c) $8 \mathrm{~m}$ section in front of the work front (close to the upper lane)

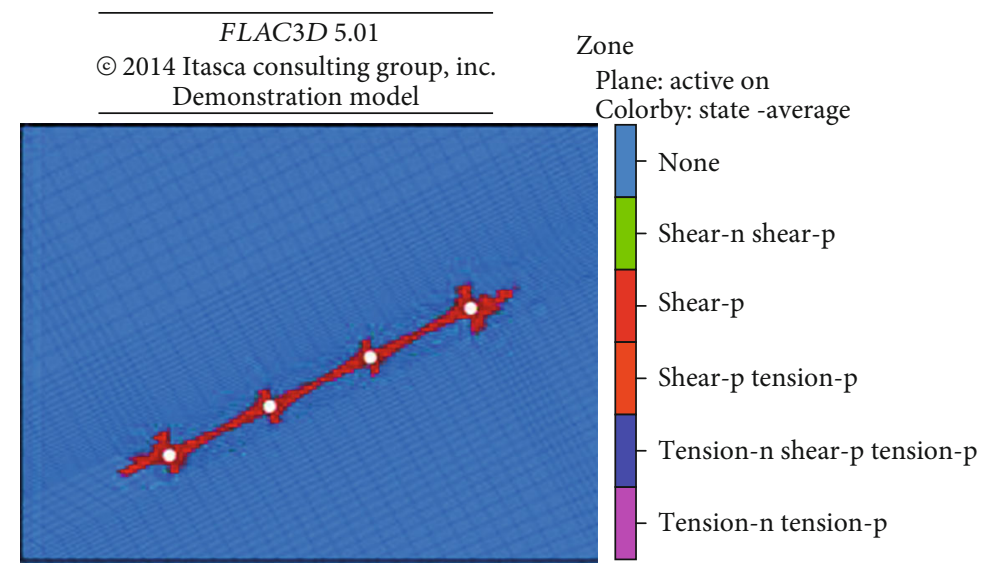

(e) $4 \mathrm{~m}$ cross section in front of the work front (close to the lower lane)

FIgURe 13: Continued. (b) $6 \mathrm{~m}$ section in front of the working face (close to the upper lane)

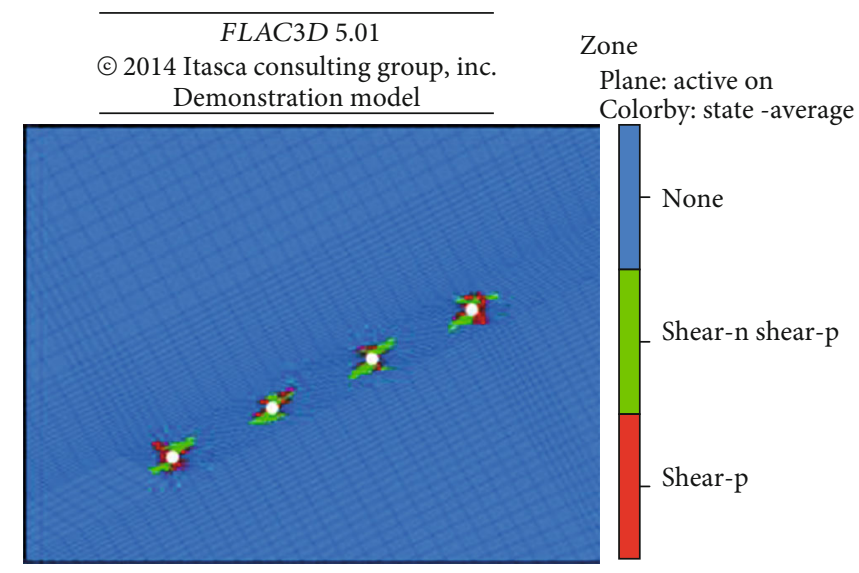

(d) $10 \mathrm{~m}$ cross section in front of the working face (close to the upper lane)

Plane: active on Colorby: state -average

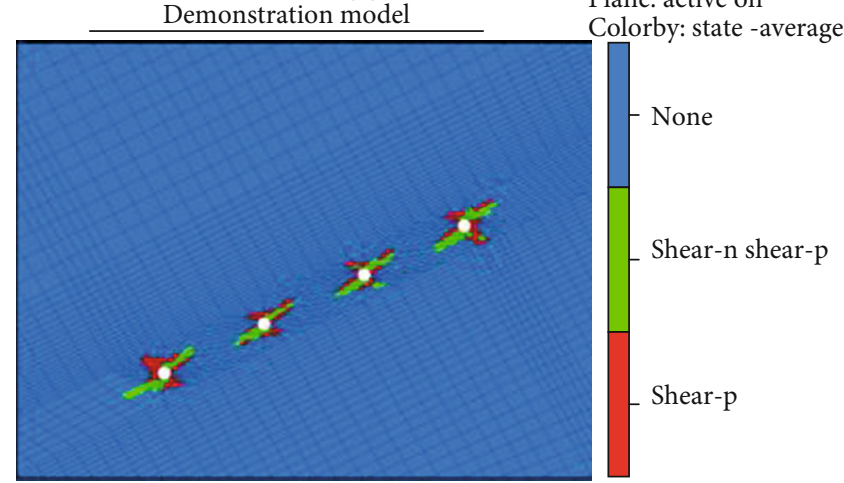




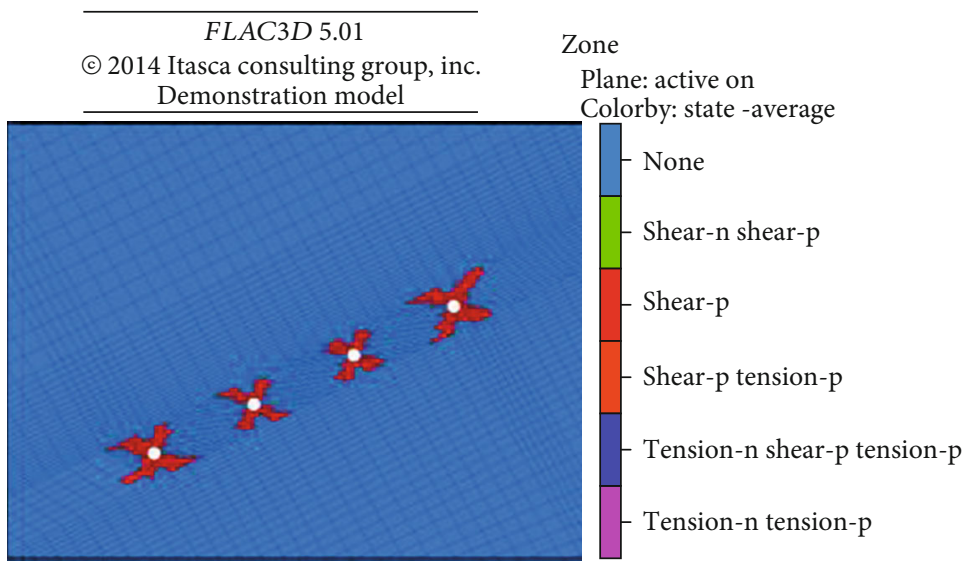

(f) $6 \mathrm{~m}$ cross section in front of the working face (close to the lower lane)

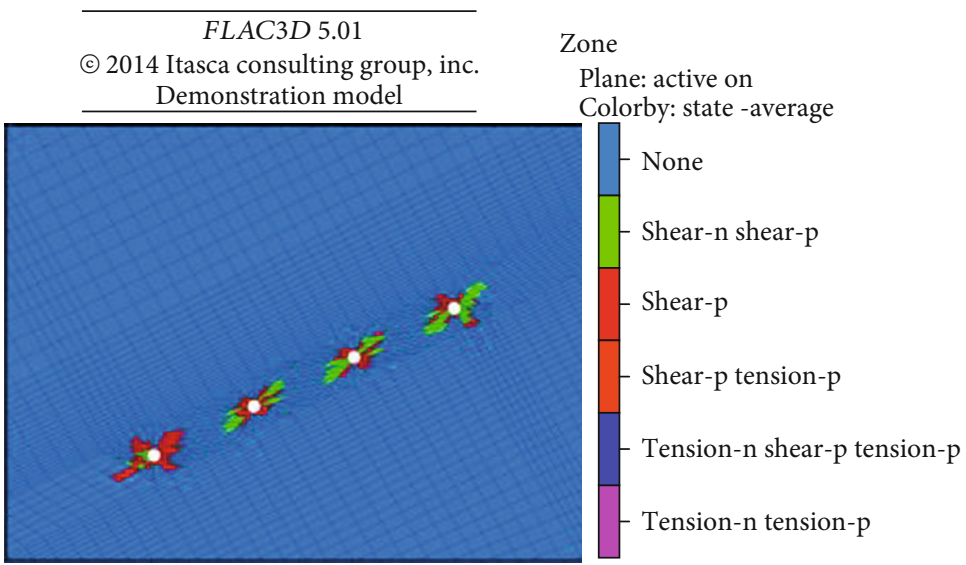

(g) $8 \mathrm{~m}$ section in front of the working face (close to the down lane)

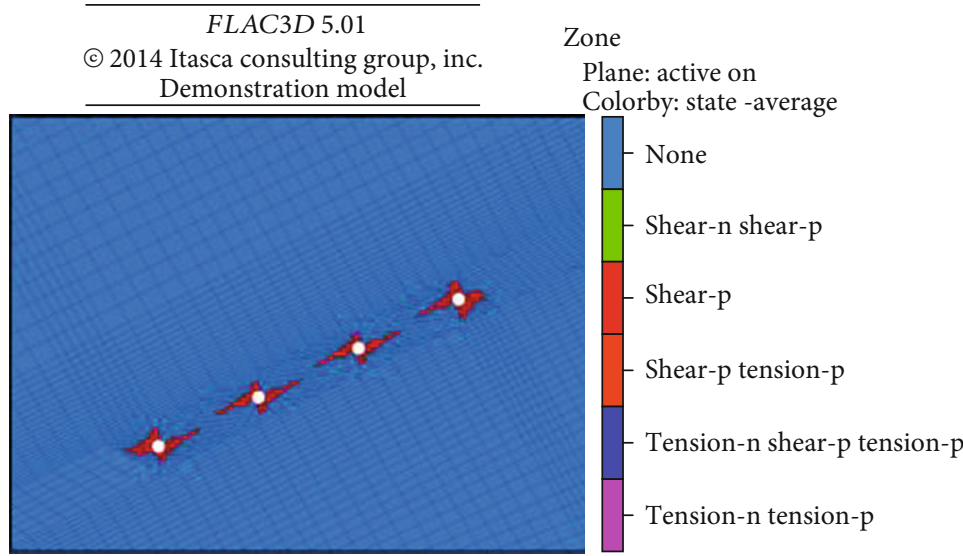

(h) $10 \mathrm{~m}$ cross section in front of the working face (close to the down lane)

FIGURE 13: The distribution of the plastic zone of drilling holes along the direction of the working face.

applicable parameters of layout directions, borehole diameters, borehole spacings, and borehole depth, which provided a basis for the actual application on site.

(1) Determining the layout direction of large-diameter boreholes

The key to prevention of rock burst on working face is whether the concentrated stress in front of the working face can be relieved. According to the unloading principle of bore- hole, it is necessary to arrange borehole in the stress concentration area to achieve the desired relief effect. The layout of large-diameter pressure-relief borehole has two layout schemes along the working face strike and along the working face trend, as shown in Figure 12.

(2) Determination of large-diameter borehole diameter

The large-diameter borehole diameters are selected from five types of apertures of $200 \mathrm{~mm}, 400 \mathrm{~mm}$, 


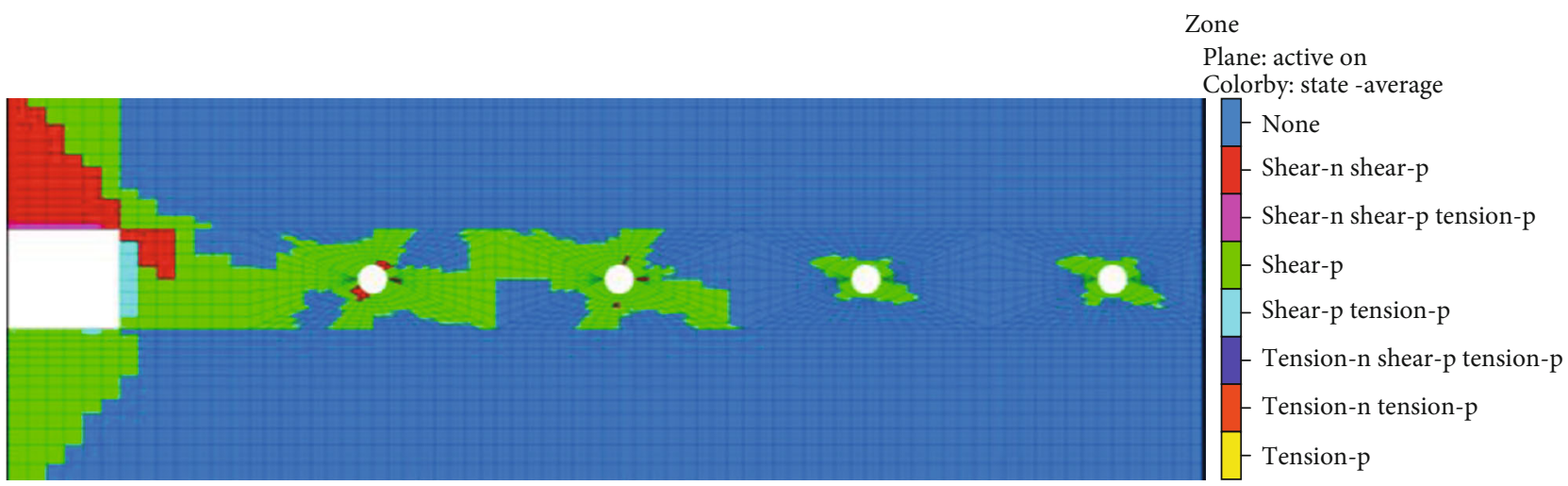

FIgURE 14: Distribution of plastic zone of boreholes along the incline of the working face.

$600 \mathrm{~mm}, 800 \mathrm{~mm}$, and $1000 \mathrm{~mm}$ for numerical simulation. The plastic failure range and distribution of surrounding rock of large-diameter borehole are compared and analyzed under different borehole size conditions, as well as the stress distribution cloud map of surrounding rock of borehole, so as to study the influence of borehole diameter on pressure-relief effect.

\section{(3) Determination of large-diameter borehole pacing}

The spacing of large-diameter pressure-relief drilling holes was selected $2.5 \mathrm{~m}, 5.0 \mathrm{~m}, 7.5 \mathrm{~m}$, and $10 \mathrm{~m}$ for numerical simulation. In order to study the influence of borehole spacing on pressure-relief effect, the damage degree of the mutual spatial relation of plastic zone of surrounding rock of large-diameter borehole and the stress distribution cloud map of surrounding rock of borehole are compared and analyzed under different borehole spacing conditions.

(4) Determination of the depth of large-diameter boreholes

The large-diameter pressure-relief boreholes with depths of $30 \mathrm{~m}, 45 \mathrm{~m}, 60 \mathrm{~m}$, and $75 \mathrm{~m}$ were drilled into the coal body for numerical simulation. The influence of borehole depth on pressure-relief effect is studied by comparing and analyzing the failure degree of plastic zone of different borehole depths.

\subsection{Numerical Simulation Results}

4.3.1. Different Layout Directions. Along the direction of the working face strike, four large-diameter pressure-relief boreholes with a diameter of $600 \mathrm{~mm}$ are, respectively, arranged near the upper lane and lower lane in working face and the roadway, and numerical simulation calculation is carried out. Numerical simulation results of the plastic zone of surrounding rocks in the large-diameter pressure-relief boreholes were analyzed.

It can be seen from the Figure 13 that the plastic zone of the pressure-relief drilling $6 \mathrm{~m}$ before the working face no longer affects each other, and the pressure-relief effect becomes worse as it goes forward.
Figure 14 shows the arrangement of large-diameter pressure-relief boreholes along the inclined direction of the working face. It can be seen from the figure that, with the advance of the working face, the peak value of abatement pressure moves forward continuously. At the same time, because of the mining action of the working face, the stress value on the horizontal side of the pressure-relief borehole reduces the pressure-relief pressure. Therefore, the largediameter pressure-relief borehole surrounding rock is under the non-uniform stress field, and butterfly-shaped failure occurs in the plastic zone of the borehole surrounding rock. It can be seen from the figure that the butterfly-shaped plastic zone of surrounding rock of the pressure-relief borehole is interconnected with each other, releasing concentrated stress 10 meters ahead of the working face, reducing elastic energy, and achieving the purpose of preventing rock burst.

Through numerical simulation of different arrangement methods of large-diameter pressure-relief borehole, it can be seen that the arrangement of large-diameter pressurerelief borehole along the working face trend direction has better effect than that along the working face strike direction.

4.3.2. Different Apertures. In Figure 15, in front of the working face, large-diameter pressure-relief boreholes with diameters of $200 \mathrm{~mm}, 400 \mathrm{~mm}, 600 \mathrm{~mm}, 800 \mathrm{~mm}$, and $1000 \mathrm{~mm}$ were arranged, and numerical simulation was carried out. Then, the simulation results of vertical stress distribution cloud map and horizontal stress distribution cloud map of the plastic zone of surrounding rock of the borehole were analyzed, and the optimal aperture scheme was obtained.

(1) Analysis of Surrounding Rock Plastic Zone. Through analysis, it can be seen that with the continuous increase of the diameter of the pressure-relief borehole, the plastic zone distribution of the surrounding rock of the boreholes gradually increases, which conforms to the results of the previous theoretical analysis, and the plastic zone of the surrounding rock of the boreholes is positively correlated with the diameter of the borehole. However, from the perspective of plastic zone distribution and depth failure distribution, it is more reasonable to arrange $600 \mathrm{~mm}$ large-diameter pressure-relief borehole in front of the working face. 


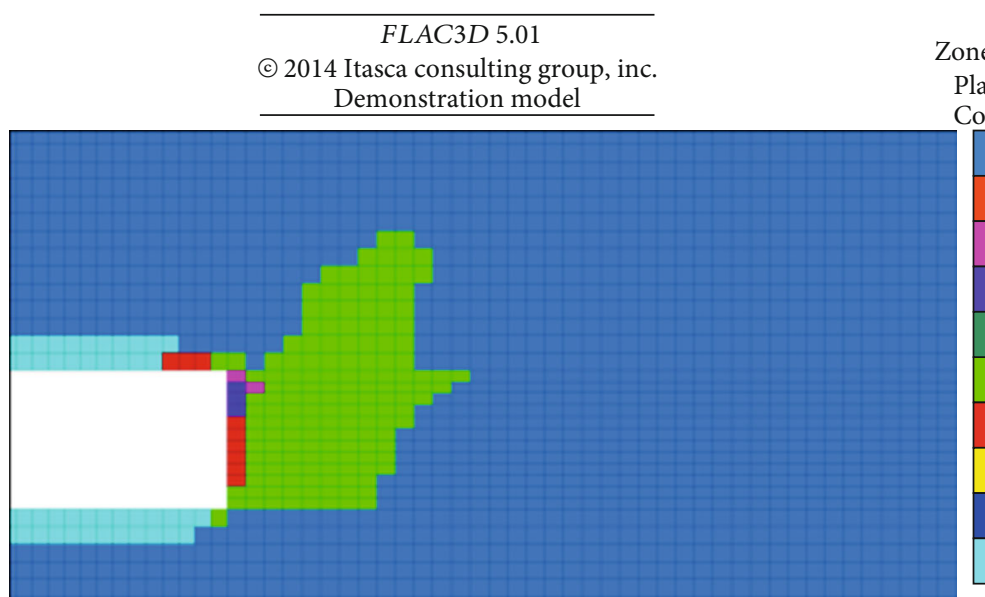

Zone

Plane: active on

Colorby: state -average

- None

Shear-n

Shear-n shear-p

Shear-n shear-p tension- $\mathrm{p}$

Shear-n tension- $n$ shear-p tension- $p$

Shear-p

Shear-p tension-p

Tension-n shear-p tension- $p$

Tension-n tension-p

(a) No boreholes

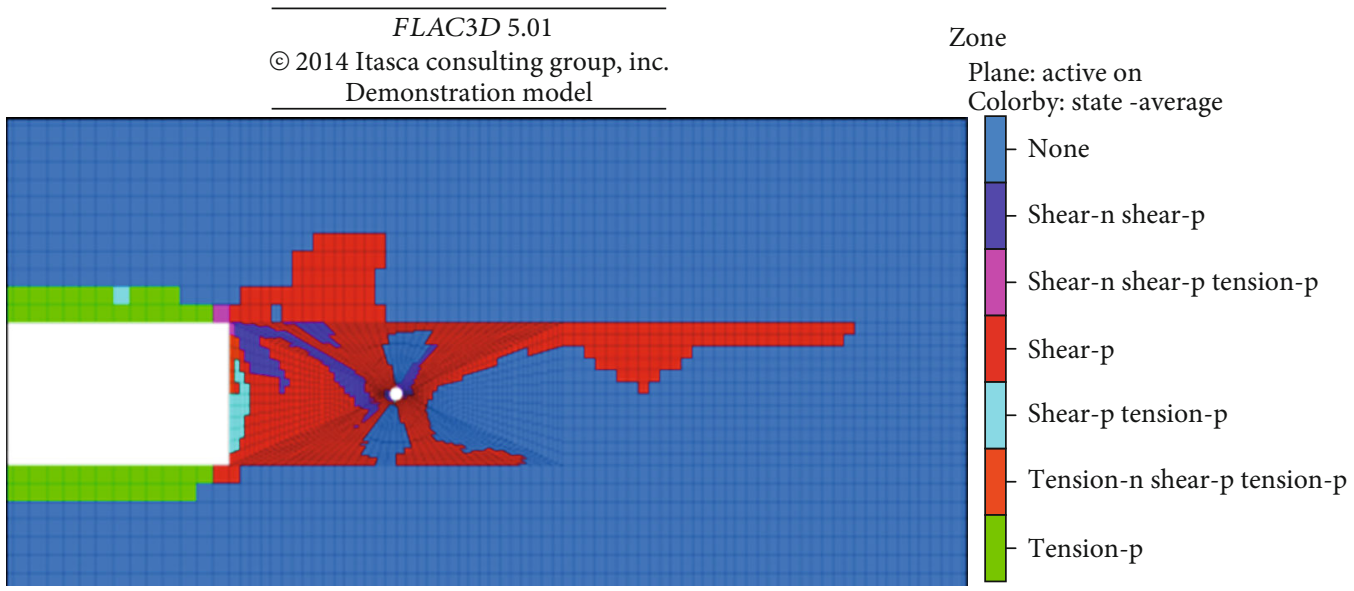

(b) Borehole diameter $200 \mathrm{~mm}$

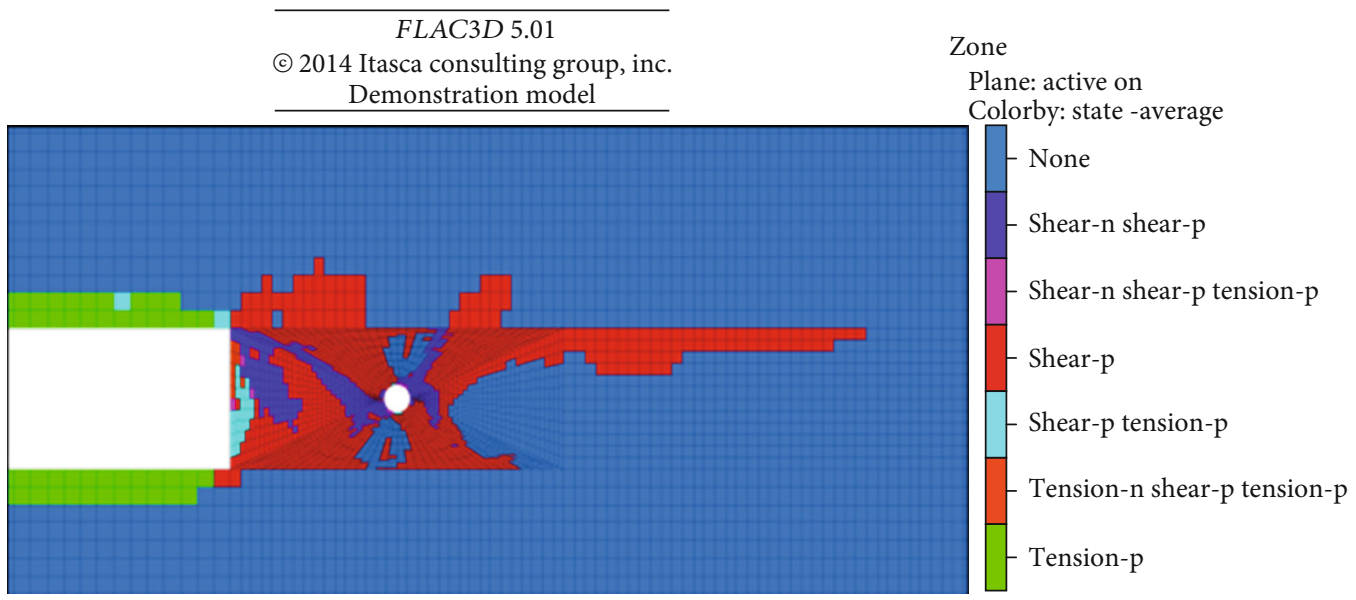

(c) Borehole diameter $400 \mathrm{~mm}$

FIgURE 15: Continued. 


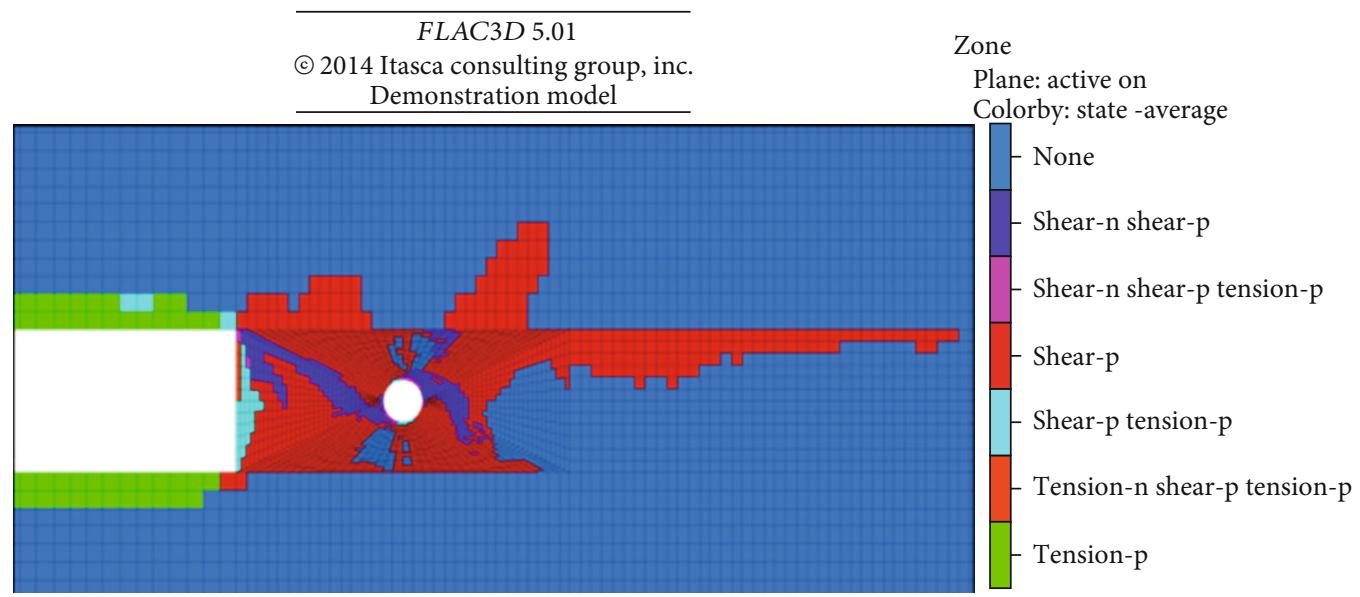

(d) Borehole diameter $600 \mathrm{~mm}$

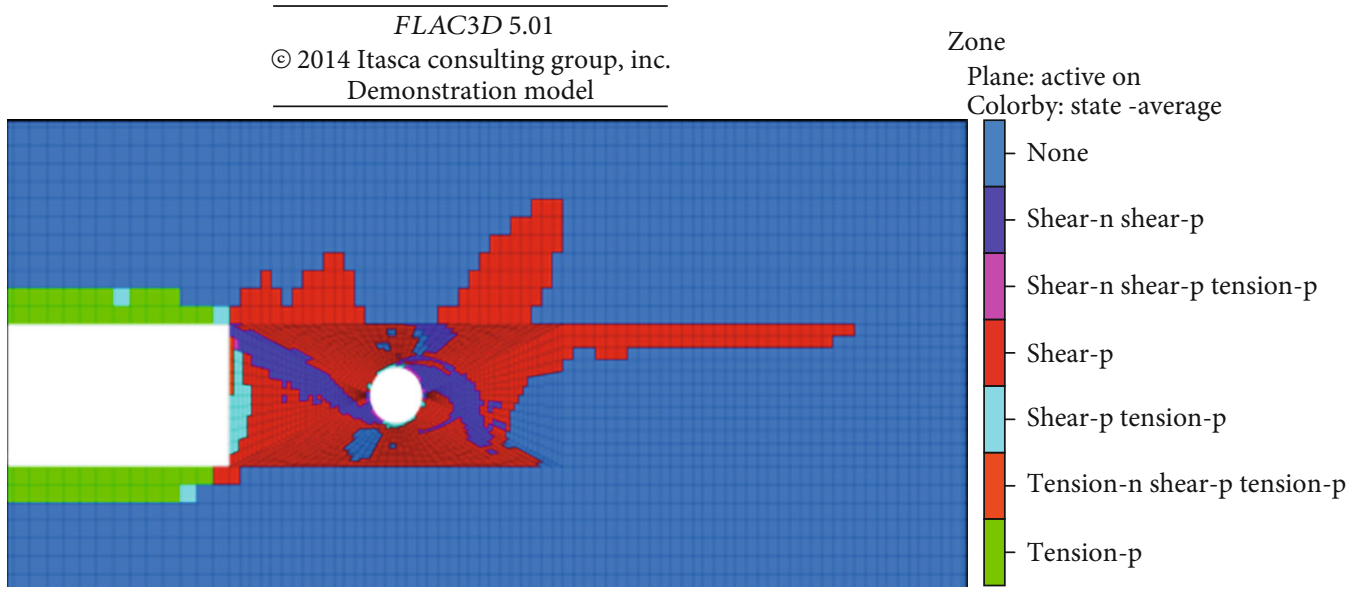

(e) Borehole diameter $800 \mathrm{~mm}$

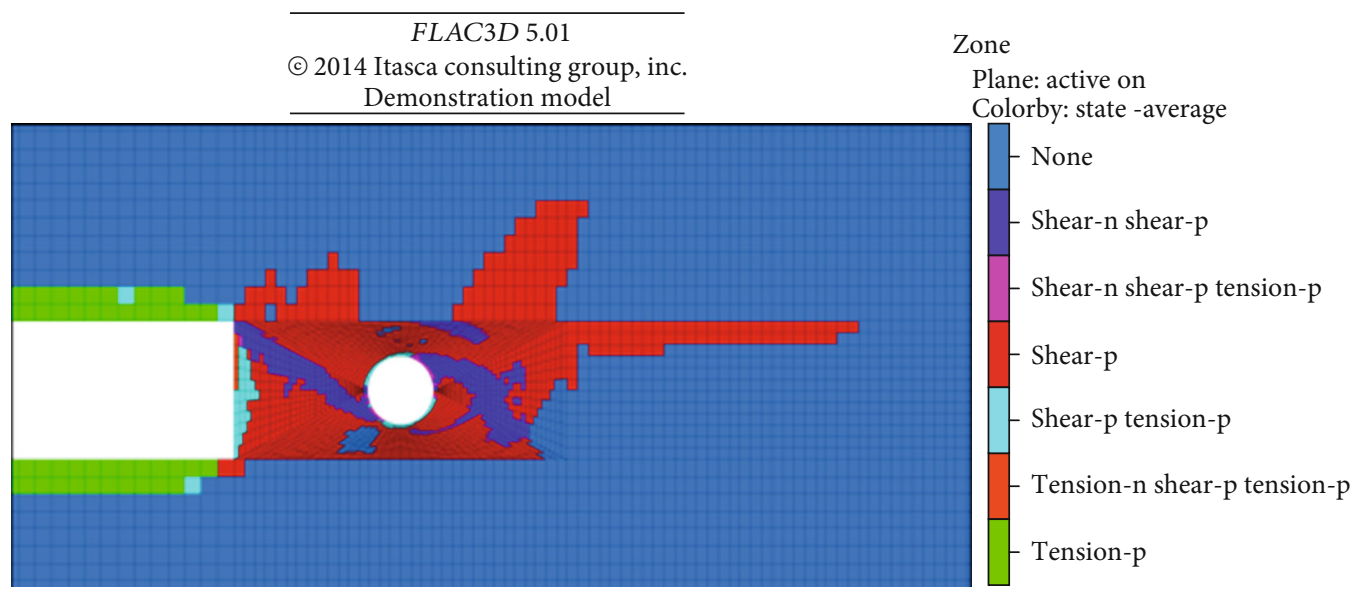

(f) Borehole diameter $1000 \mathrm{~mm}$

Figure 15: Distribution of plastic zone under different apertures.

4.3.3. Different Hole Spacings. In Figure 16, two largediameter pressure-relief boreholes with a diameter of $600 \mathrm{~mm}$ are arranged in front of the work face, and the hole spacing of the pressure-relief boreholes is $2.5 \mathrm{~m}, 5.0 \mathrm{~m}$, $7.5 \mathrm{~m}$, and $10 \mathrm{~m}$, respectively. Then, the simulation results of vertical stress distribution cloud map and horizontal stress distribution cloud map in plastic zone of surrounding rock of borehole are analyzed, and the optimal plan of borehole spacing is obtained.

(1) Analysis of Surrounding Rock Plastic Zone. According to the above analysis, when the distance between two largediameter pressure-relief boreholes is $5.0 \mathrm{~m}$, the plastic zone of the borehole can be transfixed. Consider that in practice, 


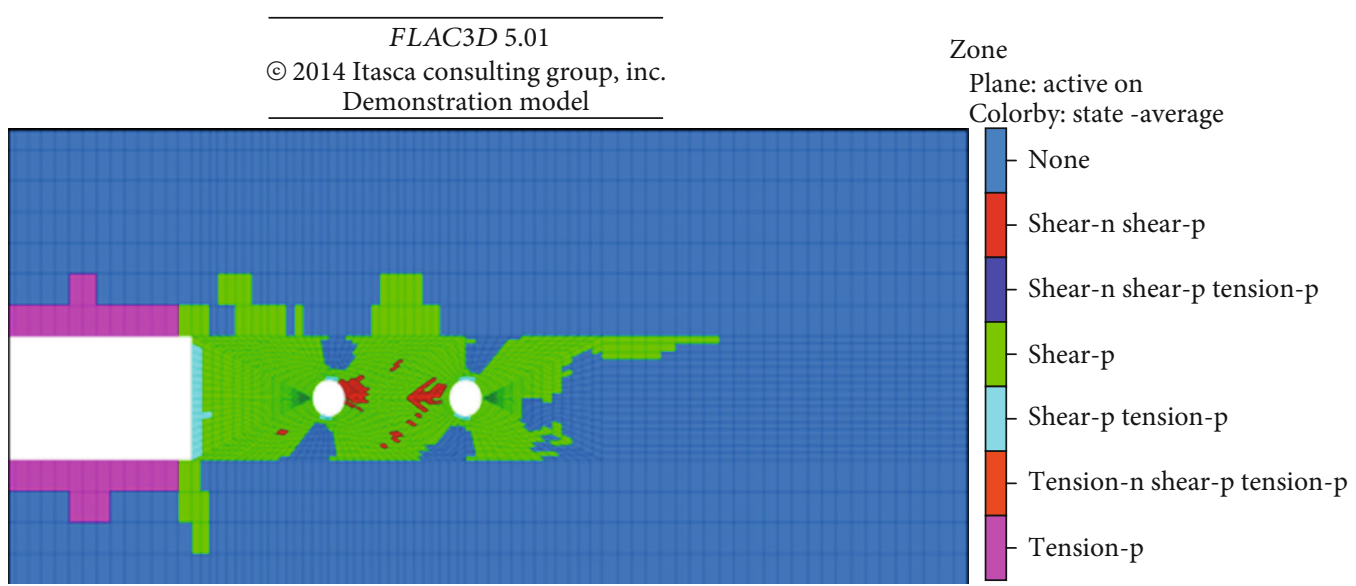

(a) The hole spacing is $2.5 \mathrm{~m}$

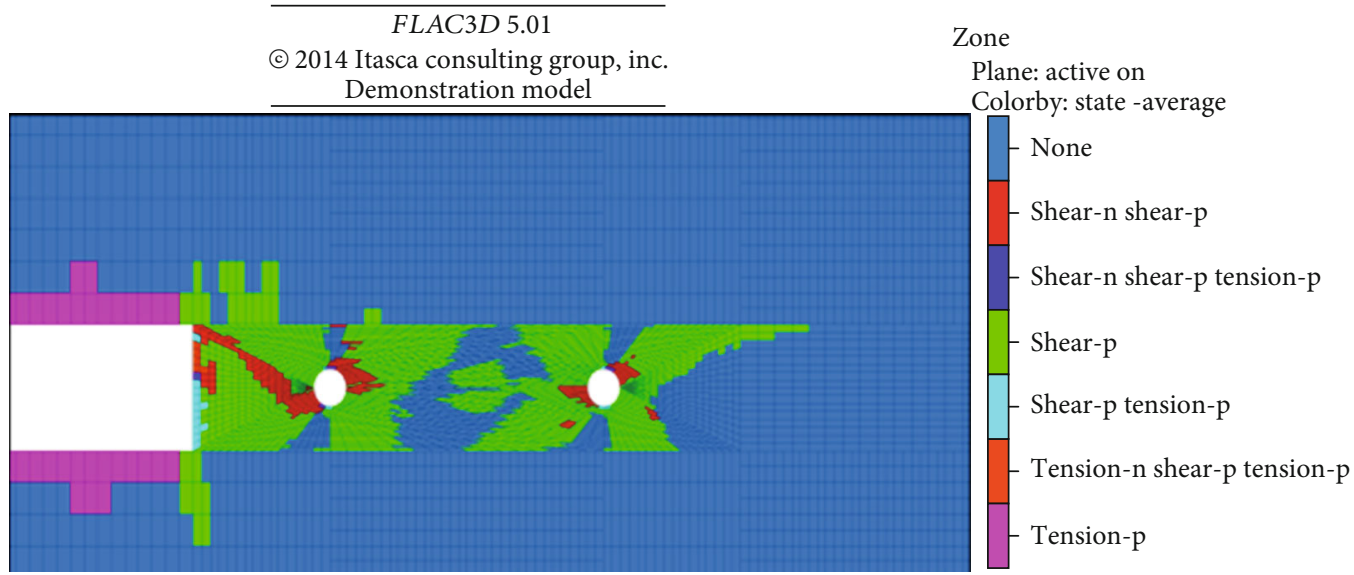

(b) The hole spacing is $5.0 \mathrm{~m}$

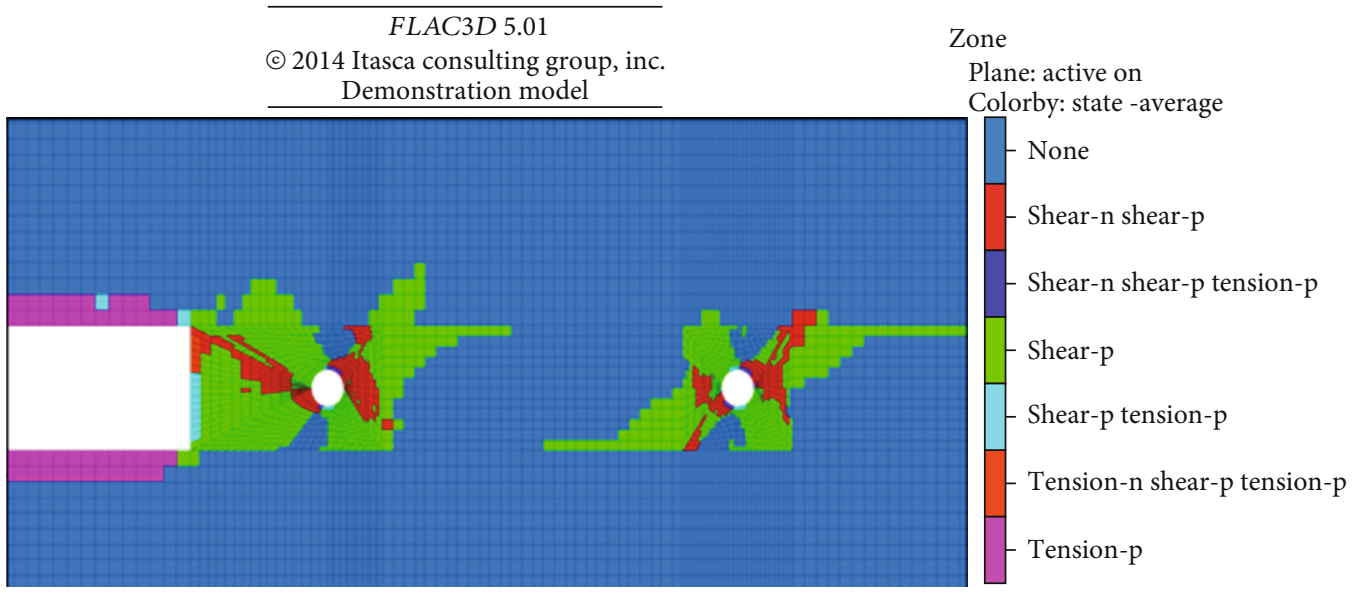

(c) The hole spacing is $7.5 \mathrm{~m}$

Figure 16: Continued. 


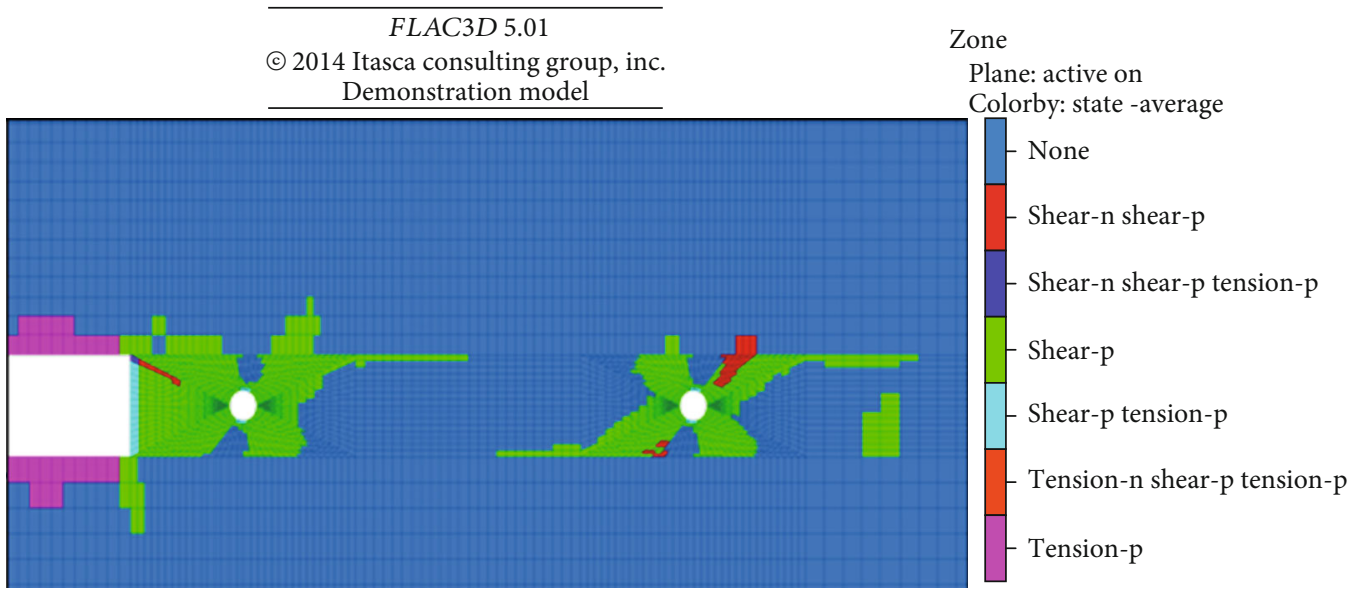

(d) The hole spacing is $10.0 \mathrm{~m}$

FIgURe 16: Plastic zone distribution under different hole spacings.

the plastic zone of the front and rear boreholes will continue to expand as the working surface advances. At the same time, the butterfly leaf of the "butterfly-shaped plastic zone" of the pressure-relief boreholes with a diameter of $600 \mathrm{~mm}$ can form a large plastic zone of more than $5 \mathrm{~m}$, so it is reasonable to set the spacing of the large-diameter pressure-relief boreholes to $7.5 \mathrm{~m}$.

4.3.4. Different Hole Depths. Along the inclination direction of the working face, four types of $600 \mathrm{~mm}$ large-diameter pressure-relief boreholes with depths of $30 \mathrm{~m}, 45 \mathrm{~m}, 60 \mathrm{~m}$, and $75 \mathrm{~m}$ are drilled into the coal body, and numerical simulation is performed, and then, the plastic zone of the pressure-relief borehole surrounding rock is simulated; then, analyze the results and get the best hole depth plan.

Three cut planes are made on the axis of the vertical large-diameter borehole, and the cut planes, respectively, pass through the bottom of the hole and $2 \mathrm{~m}$ at the front and back sides of the bottom of the hole, and then, analyze the plastic zone of the surrounding rock.

As can be seen from Figure 17 that from $-2 \mathrm{~m}$ to $0 \mathrm{~m}$ in $30 \mathrm{~m}, 45 \mathrm{~m}, 60 \mathrm{~m}$, and $75 \mathrm{~m}$ large-diameter boreholes, the butterfly leaf range on the right side of the butterfly-shaped plastic zone of the surrounding rock of the drilled hole gradually decreases, and the depth of the left roof plastic zone basically remains constant. From $0 \mathrm{~m}$ to $2 \mathrm{~m}$, there is no pressurerelief borehole effect, and the depth of the plastic zone on the roof above the work surface is gradually deepening. Affected by disturbances, rock bursts are prone to occur. It can be seen from the analysis that after the axial direction of the borehole exceeds the respective depth, the pressure-relief effect in front of the working face becomes worse and the plastic zone of the roof is distributed greatly. Therefore, through comparison, the pressure-relief effect can be carried out by using the large-diameter borehole through the working face.

In summary, the 41051 working face of the 65 -bed coal of Qitaihe Xinxing Coal Mine adopts large-diameter boreholes arranged along the inclined direction of the working face, with a hole diameter of $600 \mathrm{~mm}$ and a hole spacing of $7.5 \mathrm{~m}$, and it is arranged through the whole working face to prevent and control ground pressure impact.

\section{Field Test}

5.1. Measuring Point Arrangement. According to the working principle of the electromagnetic radiation monitor and the monitoring range of the antenna, a measuring point is arranged on the coal bank of the roadway every $5 \mathrm{~m}$ from the upper end of the roadway $5 \mathrm{~m}$ away from the working surface, and the antenna is always kept at the working distance as the working surface goes on. Within the range of 5-15 m, use KBD7 electromagnetic radiation monitor.

The first measuring point in the working face is arranged $5 \mathrm{~m}$ away from the upper lane, and then, one measuring point is arranged every $10 \mathrm{~m}$, and the KBD5 electromagnetic radiation monitor is used until the whole working face is measured. The antenna layout of the electromagnetic radiator is shown in Figure 18.

\subsection{Monitoring and Prediction}

5.2.1. Threshold's Determination. According to the principles and parameters of electromagnetic radiation, through the observation of the monitoring data during the occurrence of rock burst on the 41062 working face, it is found that the average value of the maximum electromagnetic radiation intensity MAVE is closely related to the mine pressure, impact risk factors, and degree of danger, so electromagnetic radiation is determined. The average value of the maximum intensity MAVE is a sensitive indicator of electromagnetic radiation monitoring rock burst, collectively referred to as electromagnetic radiation indicator intensity.

The parameters measured in the lanes on the three-level 41062 working surface are counted in the order of electromagnetic radiation intensity from small to large, and the statistical results are shown in Table 7. 


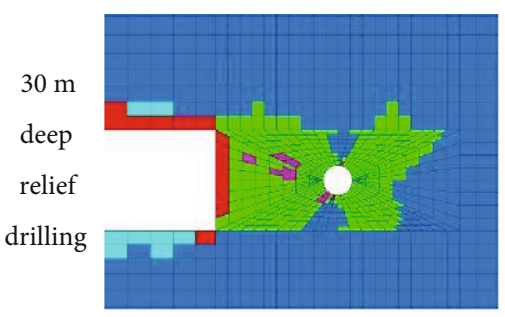

Distribution of plastic zone at $-2 \mathrm{~m}$

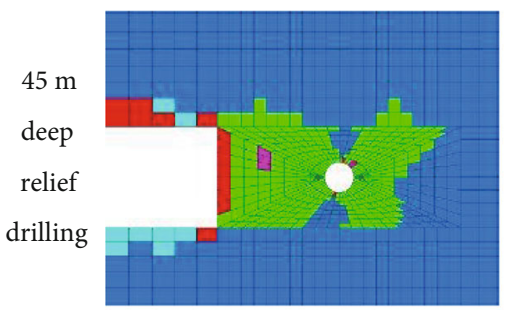

Distribution of plastic

zone at $-2 \mathrm{~m}$

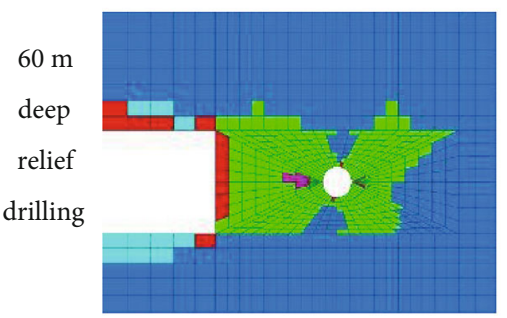

Distribution of plastic zone at $-2 \mathrm{~m}$

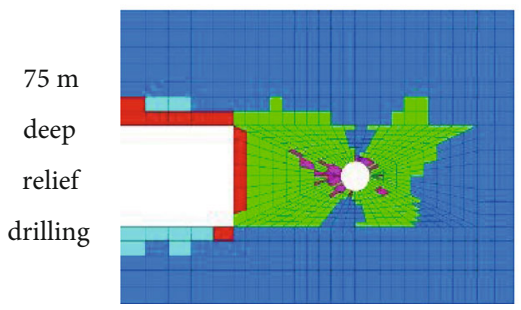

Distribution of plastic zone at $-2 \mathrm{~m}$

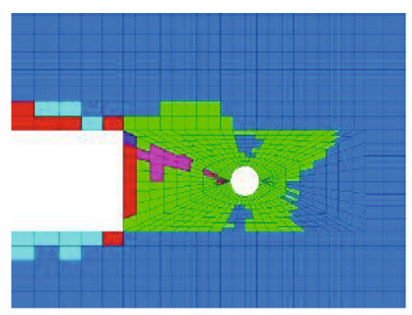

Distribution of plastic zone at $0 \mathrm{~m}$

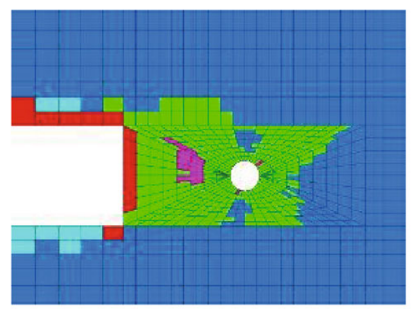

Distribution of plastic zone at $0 \mathrm{~m}$

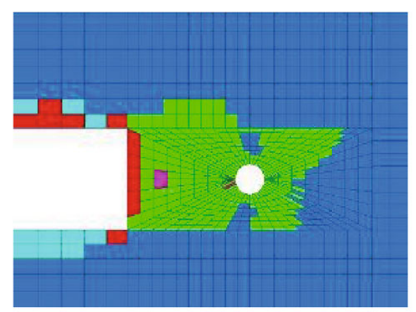

Distribution of plastic zone at $0 \mathrm{~m}$

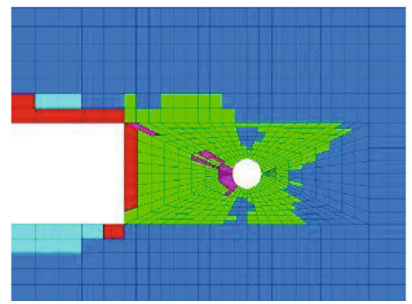

Distribution of plastic zone at $0 \mathrm{~m}$

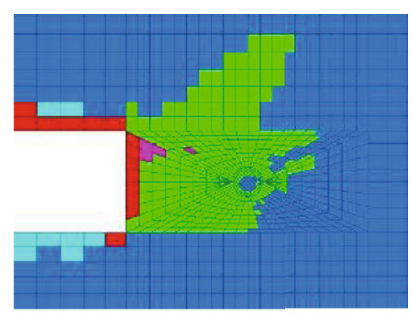

Distribution of plastic zone at $2 \mathrm{~m}$

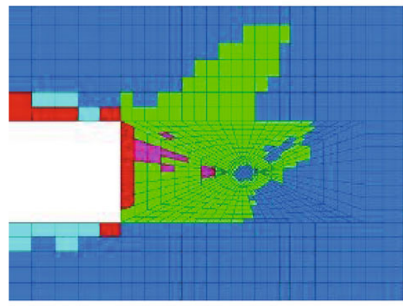

Distribution of plastic zone at $2 \mathrm{~m}$

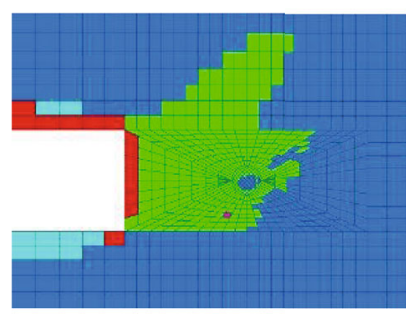

Distribution of plastic zone at $2 \mathrm{~m}$

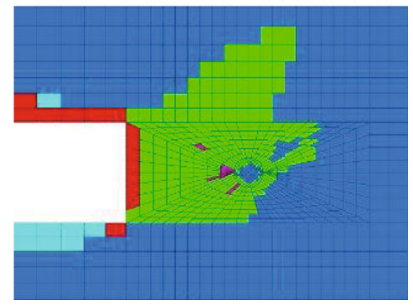

Distribution of plastic zone at $2 \mathrm{~m}$

FIGURE 17: Plastic zone distribution of each section of large-diameter boreholes with different depths.

The average value of the maximum electromagnetic radiation intensity MAVE is calculated by Formula (1) to ensure safety.

$$
\text { MAVE }=\frac{\sum_{i=1}^{8} S_{i} N_{i}}{\sum_{i=1}^{8} N}
$$

In the form $S_{i}$ is the electromagnetic radiation intensity value, $E / \mathrm{mV} ; N_{i}$ is the number of $S_{i}$ monitoring; $i$ is $1,2,3$, $4,5,6,7$, and 8 .

Calculated:

$$
\text { MAVE }=37.03 .
$$

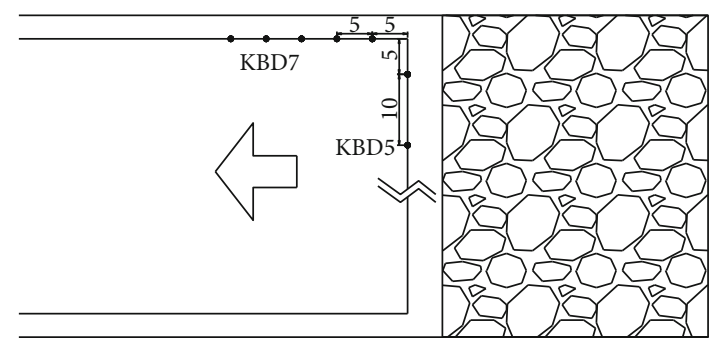

FIgURE 18: Schematic diagram of receiving antenna layout.

In the actual field measurement, under the condition of MAVE $<52.5$, almost does not have the impact pressure; therefore, $37.03 E / \mathrm{mV}$ can guarantee the safety and does not have the impact pressure. 
TABLE 7: Statistics of the frequency of electromagnetic radiation intensity monitoring.

\begin{tabular}{lcccccccc}
\hline No. & 1 & 2 & 3 & 4 & 5 & 6 & 7 & 8 \\
\hline Strength & 7.5 & 22.5 & 37.5 & 52.5 & 67.5 & 82.5 & 97.5 & 112.5 \\
Frequency & 300 & 200 & 150 & 90 & 85 & 60 & 45 & 30 \\
\hline
\end{tabular}

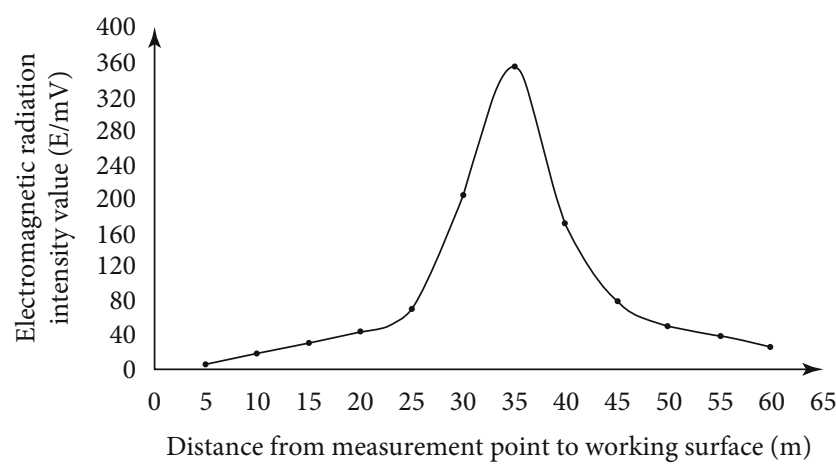

FIGURE 19: Curve of electromagnetic radiation monitoring value in the upper lane.

5.2.2. Test Results of KBD5. During the test, the base value of electromagnetic radiation is relatively low and the performance is relatively stable. Although the pressure during the test is relatively weak, according to the test analysis, the pressure is greater than $15 \mathrm{~m}$ in front of the work, MAVE > $37.03 E / \mathrm{mV}$, and within the range of $\mathrm{MAVE}<37.03 \mathrm{E} / \mathrm{mV}$, 20-30 m. Due to the effect of the large-diameter pressurerelief borehole in front of the work face, the entire pressure in front of the Xinxing mine 41501 work face appears weaker and the electromagnetic radiation intensity is low.

5.2.3. Test Results of KBD7. After a period of time monitoring, KBD7 type electromagnetic radiation monitor at the monitoring point is good KBD7 electromagnetic radiation monitoring electromagnetic signal, as far away from the working face shows the trend of first increase and then decrease, as shown in Figure 19 which is in line with the stress distribution trend of coal in front of the working face.

\section{Conclusion}

(1) By numerical simulation, the results show that the coal face in front of the coal face is affected by mining action, and the plastic zone has instantaneous malignant expansion, which then induces rock burst. And the stress of the surrounding rock of the pressurerelief borehole changes under the influence of mining; the surrounding rock of the borehole forms a large-scale "butterfly plasticity." With the advancement of the working face, the radius of the butterfly blades in the "butterfly plastic zone" of the surrounding rock of the borehole continues to expand in a sudden and sudden change, and they are connected to each other to achieve the purpose of preventing rock burst
(2) Establish a numerical simulation model of largediameter borehole relief for rock burst in Xinxing mine, and conduct simulation research on the parameters of large-diameter pressure-relief borehole-layout direction, hole diameter, hole spacing, and hole depth. The simulation results show that the layout direction of large-diameter pressure-relief drilling adopts the trend along the working face, the aperture is $600 \mathrm{~mm}$, the hole spacing is $7.5 \mathrm{~m}$, and the pressure-relief effect of the layout plan of drilling through the whole working face is the best

(3) The KBD5 and KBD7 electromagnetic radiation monitors were used to detect the effect of rock burst relief on the 41501 working face of Xinxing coal mine. The monitoring data showed that after the large-diameter borehole was relieved, the electromagnetic radiation intensity in front of the working face was significantly weakened and rock burst occurred. The possibility has been greatly reduced, and the number of impacts and the scope of impact damage of emerging mines are decreasing

\section{Data Availability}

The data used to support the study is available within the article.

\section{Conflicts of Interest}

The authors declare that they have no conflicts of interest.

\section{Acknowledgments}

This work was supported by the National Natural Science Foundation of China (Nos. 51704294 and 51434006).

\section{References}

[1] C. J. Dong, Y. S. Zhai, G. F. Su et al., "Rock burst impact factors and danger zones in Xinxing coal mine," Journal of Heilongjiang University of Science and Technology, vol. 23, no. 5, pp. 417-420, 2013.

[2] Z. H. Qin and J. F. Pan, "Research on the occurrence mechanism of rock burst in the working face of Xinxing Coal Mine," Coal Engineering, vol. 59, no. 7, pp. 64-66, 2011.

[3] Y. M. Shu and Y. L. Liu, "Research on in-situ stress test and distribution law of Xinxing Coal Mine," Coal Technology, vol. 34, no. 11, pp. 125-127, 2015.

[4] Y. M. Shu, Research on the Prevention and Control Method of Rock Burst in Emerging Coal Mines, China University of Mining and Technology (Beijing), Beijing, 2015.

[5] Y. Zhao, Y. Wang, W. Wang, L. Tang, Q. Liu, and G. Cheng, "Modeling of rheological fracture behavior of rock cracks subjected to hydraulic pressure and far field stresses," Theoretical and Applied Fracture Mechanics, vol. 101, pp. 59-66, 2019.

[6] Y. L. Zhao, C. S. Zhang, Y. X. Wang, and H. Lin, "Shear-related roughness classification and strength model of natural rock joint based on fuzzy comprehensive evaluation," International Journal of Rock Mechanics and Mining Sciences, vol. 137, article 104550, 2021. 
[7] Y. L. Zhao, L. Zhang, J. Liao, W. Wang, Q. Liu, and L. Tang, "Experimental study of fracture toughness and subcritical crack growth of three rocks under different environments," International Journal of Geomechanics, vol. 20, no. 8, article 04020128, 2020.

[8] Y. Zhao, L. Zhang, W. Wang, Q. Liu, L. Tang, and G. Cheng, "Experimental study on shear behavior and a revised shear strength model for infilled rock joints," International Journal of Geomechanics, vol. 20, no. 9, article 04020141, 2020.

[9] Y. D. Zou and L. Z. Zhao, "The application of large-diameter borehole pressure relief technology in the prevention of deep rock burst," Coal Mine Support, vol. 31, no. 1, pp. 32-34, 2014.

[10] T. W. Lan, Analysis of dynamic conditions of rock burst in Datai well and research on prevention technology, Fuxin:Liaoning Technical University, 2011.

[11] F. X. Jiang, P. Wang, and Z. Q. Feng, "The mechanism, prediction and control of shock-shock' dynamic disasters in compound thick coal seams," Journal of China Coal Society, vol. 34, no. 12, pp. 1065-1069, 2009.

[12] E. Y. Wang and E. L. Zhao, "Numerical simulation of electromagnetic radiation caused by coal/rock deformation and failure," International Journal of Rock Mechanics and Mining Sciences, vol. 57, pp. 57-63, 2013.

[13] Y. Wu and W. Li, "Study on technology of electromagnetic radiation of sensitive index to forecast the coal and gas hazards," Procedia Engineering, vol. 7, pp. 327-334, 2010.

[14] X. Erlong, Z. Xiaopin, H. Xueqiu et al., "Coupling study between rheology and electromagnetic emission of coal or rock dynamic catastrophe," Procedia Engineering, vol. 26, pp. 15711575, 2011.

[15] Y. Xue, F. Gao, T. Teng, and Y. Xing, "Effect of gas pressure on rock burst proneness indexes and energy dissipation of coal samples," Geotechnical and Geological Engineering, vol. 34, no. 6, pp. 1737-1748, 2016.

[16] D. Song, E. Wang, C. WANG, and F. Xu, "Electromagnetic radiation early warning criterion of rock burst based on statistical theory," Mining Science and Technology (China), vol. 20, no. 5, pp. 686-690, 2010.

[17] C. Wang, E. Y. Wang, and X. F. Liu, Research on the Unascertained Measure Mathematical Model of the Comprehensive Evaluation of Rock Burst Risk, China University of Mining and Technology Press, Xuzhou, 2014.

[18] M. Nianjie, G. Xiaofei, and Z. Xidong, “Theoretical analysis and application of borehole penetration enhancement radius for coal and gas mining," Journal of China Coal Society, vol. 41, no. 1, pp. 120-127, 2016.

[19] D. F. Sun and B. Liu, "Numerical simulation study on optimization of pressure relief depth for large diameter boreholes," Coal Technology, vol. 35, no. 8, pp. 155-156, 2016.

[20] M. T. Zhang, "Forecast and prevention of rock burst in China," Journal of Liaoning Technical University, no. 8, pp. 433-435, 2001.

[21] Q. X. Qi, Y. W. Shi, and T. Q. Liu, "Experimental study on stick-slip instability mechanism of rock burst," Journal of China Coal Society, vol. 22, no. 2, pp. 144-148, 1997.

[22] M. Nianjie, L. Ji, and Z. Xidong, "High- quality gas channel and its construction method in deep coal and gas mining," Journal of China Coal Society, vol. 40, no. 4, pp. 742-748, 2015.

[23] N. J. Ma and C. J. Hou, "A research into plastic zone of surrounding strata of gateway affected by mining abutment stress," in Proc. of the 32nd U.S. Symposium on Rock Mechanics, pp. 90-92, Golden, CO, USA, 1990.

[24] G. Xiaofei, M. Nianjie, and Z. Xidong, "The general shape of the plastic zone in the surrounding rock of a circular roadway and its judgment criteria," Journal of China Coal Society, vol. 41, no. 8, pp. 1871-7877, 2016.

[25] Z. Q. Zhao and N. J. Ma, "Discussion on the stability of roadway surrounding rock and the connotation of butterfly failure theory-response to discussion on driftway butterfly failure theory and its application prospect," Journal of China University of Mining and Technology, vol. 25, no. 3, pp. 685-692, 2019.

[26] X. Gao, S. Zhang, and Y. Zi, "Study on optimum layout of roadway in close coal seam," Arabian Journal of Geosciences, vol. 13, no. 13, p. 746, 2020.

[27] X. F. Guo, Z. Q. Zhao, and X. Gao, “Analytical solutions for characteristic radii of circular roadway surrounding rock plastic zone and their application," International Journal of Mining Science and Technology, vol. 29, no. 29, pp. 263-272, 2019.

[28] X. F. Guo, Z. Q. Zhao, and X. Gao, "Directional sharp-point failure mechanism of rocks surrounding underground circular cavities subjected to large-scale failure," Mathematical Problems in Engineering, vol. 2019, 2019.

[29] H. S. Jia, L. Y. Wang, and S. W. Liu, "Mechanism and control strategy of asymmetrical floor heave of coal pillar roadway in fully mechanized caving face," Journal of China Coal Society, vol. 44, no. 4, pp. 1030-1040, 2019. 